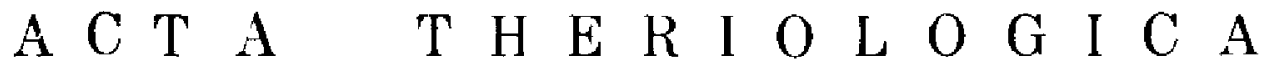

VOL. $20,29: 379-434$

August, 1975

\author{
Marek G E B C Z Y Ń K I
}

\section{Heat Economy and the Energy Cost of Growth in the Bank Vole during the First Month of Postnatal Life *}

[With 13 Tables \& 10 Figs.]

The body temperature of the bank vole, Clethrionomys glareolus ( $\mathrm{s} \mathrm{ch} \mathrm{r} \mathrm{e} \mathrm{ber,} \mathrm{1780),} \mathrm{is} 33-34^{\circ} \mathrm{C}$ at the age of $1-9$ days. This is followed by an even increase in temperature from the tenth to eighteenth day of life, reaching the adult level of $37-39^{\circ} \mathrm{C}$ by about the $19 \mathrm{th}$ day of life. Measurements made in the laboratory at ambient temperatures of $18-21^{\circ} \mathrm{C}$ and $4-7^{\circ} \mathrm{C}$, and also in an enclosure at $2-12^{\circ} \mathrm{C}$, show that the body temperature of bank voles in the nest is subject to only slight fluctuations. The thermal conditions of nest development are thus characterized by stability, maintaining the body temperature of rery young voles at a high and stable Ievel. During the first week of life the voles' resistance to cooling is low and atthough it increases gradually with age, it is not until the end of the second week of life that it becomes distinct. Voles kept together in a litter have a greater resistance to cooling (up to $33 \%$ ) than separated animals. The nest forms an even greater protection as it can produce a five-fold reduction in the rate of fall of body temperature in young voles. In addition, maternal behaviour, manifested inter alia in extensive warming of the young, makes the offspring independent of the effects of their environment. The metabolic rate of newborn voles is low and only increases towards the end of the second week of life. However, the effect of cooling for 15 minutes causes a distinct increase in oxygen consumption even during the first few days after birth. In individuals from $10-18$ days old oxygen consumption at 15 and $20^{\circ} \mathrm{C}$ is higher than in older animals, suggesting the development of heat-producing mechanisms and lack of heat conservation mechanisms. Metabolic reaction to cold in individuals from litters of 1 vole only may be twice as high as that in litters of 3 or more young. The metabolic rate of individuals separated for the time required to make measurements in no way describes the litters from which they were taken, since it is usually higher and less dependent on age. The increase in energy requirements necessary to rear young is about $10 \mathrm{kcal}$ of assimilated energy per $1 \mathrm{~g}$ of litter weight gain. It depends only on the rate of increase in body weight of the offspring, since it was similar in the winter group growing slowly at an ambient temperature of $20^{\circ} \mathrm{C}$ and in the spring group growing quickly at 9 and $20^{\circ} \mathrm{C}$. The amount of energy accumulated by newborn roles on the

* Praca została zrealizowana w ramach problemu węzłowego 09,1,7. koordynowanego przez Instytut Ekologii PAN. 
first few days after birth may be as much as $60 \%$; in voles $10-18$ days old it fluctuates between 10 and $20 \%$, whereas in older animals it does not exceed $5 \%$, Thus the low metabolic rate of nestling voles and maternal care enables this species to create favourable conditions for the derelopment of the young with a minimum expenditure.

1. General introduction

A. Physiological and behavioural aspects of body temperature regulation

2. Body temperature and resistance to cooling . . . . . . . . . 383

2.1. Material and methods . . . . . . . . . . . . . . . . 383

2.2. Ways of measuring body temperature. 384

2.3. Postnatal changes in body temperature . . . . . . . . . 385

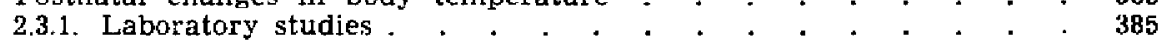

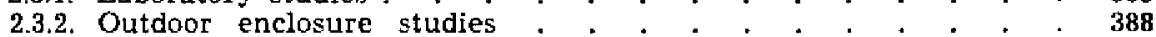

2.4. Development of resistance to cooling . . . . . . . . . . . 388

2.5. Discussion . . . . . . . . . . . . . . . . . . 391

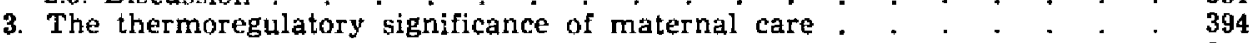

3.I. Material and method . . . . . . . . . . . . . . . . . . 395

3.2. Laboratory observations . . . - . . . . . . . . . . 395

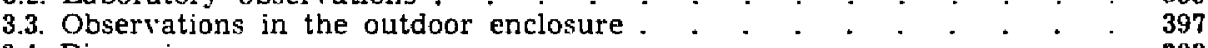

3.4. Discussion - 398

4. Metabolic rate at different ages and at different ambient temperatures . . $\quad 399$

4.1. Material and methods. . . . . . . . . . . . . . 400

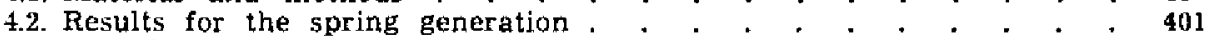

4.2.1. Litter size and oxygen consumption. . . . . . . . . . 401

4.2.2. The effect of ambient temperature on the metabolic rate of single individuals of different ages... . . . . . . 403

4.2.3. The effect of ambient temperature and the size of the litter (2-6 young) on the metabolic rate at different ages. . . . 407

4.3. Hesults for the autumn generation . . . . . . . . . 410

4.3.1. Litter size and oxygen consumption . . . . . . . . 410

4.3.2. The effect of age and temperature on metabolic rate . . . . 410

4.4. Differences between generations . . . . . . . . . . . . . 412

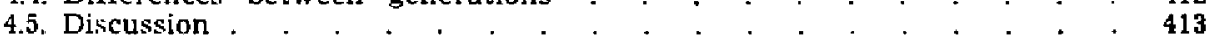

B. The energy cost of nestling development

5. The cost of growth in nestlings at different temperatures. . . . . 4]5

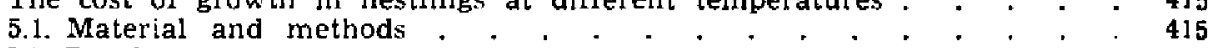

5.2. Results . . . . . . . . . . . . . . . + . . . 416

5.3. Discussion . . . . . . . . . . . . . . . . . 418

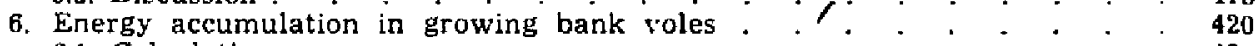

6.1. Caleulations . . . . . . . . . . . . . . . . . 420

6.2. Discussion . . . . . . . . . . . . . . . . 422

7. General discussion. . . . . . . . . . . . . . . . . 423

References . . . . . . . : . : . . . . . . . . . 427

Streszczenie

\section{GENERAL INTRODUCTION}

Not all mammals are born with the capacity for effectively maintaining a constant body temperature. In many species, chiefly Micromammalia, thermoregulatory mechanisms gradually develop after birth. The lack of the capacity for maintaining the body temperature similar to that of adult animals suggests that the role of this character and the growth conditions connected with it depend on random factors and may therefore be characterized by considerable variability. The assumption that body temperature is variable finds some confirmation in the data collected 
up to the present, which indicate that in young mammals it fluctuates with the ambient temperature (Gelineo \& Gelineo, 1951; Precht, Christopherson \& Hensel, 1955; Capek, Hahn, Kŕečk \& Martinek, 1956; Pucek, 1958; Gelineo, 1959 and others).

Thus while much information is to be found on the absence of a constant body temperature after birth in many mammals, we know very little about the thermal environment in which the young of these species grow. The question then arises as to whether the rapid growth characteristic of postnatal life takes place independently of the effect of the environment. If this is so, then is this kind of development comparable with the development of mammal species born with a fully developed thermoregulatory apparatus?

The bank vole, Clethrionomys glareolus ( $\mathrm{Schreber}, 1780$ ), was chosen as the study animal as it is a rodent which at birth is completely helpless and which spends the first weeks of life with other members of the litter in the nest under maternal care. The naked newborn voles gradually become covered by hair during the first 10 days of life, but the true development of their fur takes place at the age of 19-20 days ( $\mathrm{S} v \mathrm{iridenko}, 1959 ; \mathrm{Maz}$ ak, 1962). The eyes of this species do not (rpen until the 11 th to 15 th day after birth (Sviridenko, 1959; Petrov \& Airapetjanc, 1961). Its secretive lifestyle accounts for the fact that we do not know definitely whether the young can leave the nest for a short period at the age of $14-15$ days (P e trov \& A ir a pet $j$ a n $c, 1961$ ), although at the age of three weeks they become part of the trappable population (Bujalska, Andrzejewski \& Petrusewic $z, 1968$ ). Bank voles are thus born completely incapable of independent life, but by the fourth week of life are sufficiently developed to become independent of their parents.

The first month of life in this species is characterized by a very rapid increase in body weight; from about $2 \mathrm{~g}$ at birth ( $\mathrm{S} \mathrm{v}$ i $\mathrm{r}$ ide $\mathrm{nk}$, $1959 ; \mathrm{Zejda}, 1968$ ) they attain the weight of $11-15 \mathrm{~g}$ on the 30th day of life (D rożdz, 1965; Bujalska \& Gliwicz, 1968; Fedyk, 1974a; Sawicka-Kapusta, 1974). Changes in body size are accompanied by the development of physiological functions (B a s he $\mathrm{n}$ in a \& Borovskaja, 1963; Okon, 1972; Kostelecka-Myrcha, 1973 ) resulting in young animals having similar indices of these functions to adults towards the end of the first month of life.

The rate of postembryonic development is dependent on the season in which the young were born (B e r g stedt, 1965; K ubik, 196.; Bujalska \& Gliwicz, 1968; Zejda, 1971). Individuals from litters born in spring (spring generation) have a different gross body 
composition even at birth than the young of the autumn generation and attain chemical maturity at a different rate (F ed $y \mathrm{k}, 1974 b)$. Both generations show differences in the tissue oxygen consumption rate of growing voles (Gębczynski, 1975). There is therefore no doubt that studies of metabolic rate and development conditions must be related to the different seasons of birth. The postnatal development of the vole is to a certain degree connected with the number of young in the litter (Korabelnikov, 1972; Pegelman \& Korabelni$\mathrm{kov}, 1972$ ), and their survival during the period of nest life (Rys zkowski \& Truszkowski, 1970). It is therefore essential that this factor is taken into account when measuring the development of physiological indices.

All the above conditioning of development and growth during the period from birth to independent life does not conceal the fact that it is what helps the bank vole to maintain high population numbers. This rodent inhabits enormous regions of Europa and Asia and is considered as one of the dominating species in forest areas of the temperate zone. It may therefore be assumed that these particular properties of their postnatal development form a favourable basis for maintaining high number of bank voles.

The purpose of the study was to obtain information not only on the physiological reactions of bank voles during the first month of their lives, but also to evaluate the real living conditions of young voles. Measurements were therefore aimed at defining the potential capacities of this species, the course taken by changes occuring with age and the natural range of fluctuations in the parameters examined. Body temperature, resistance to cooling, oxygen consumption at different temperatures and the energy budget were measured in growing voles. This made it possible to calculate the growth efficiency of the young voles and to compare it with other species of homeothermic animals. The effect of litter size and maternal care on the rate of development of the measured physiological functions were also taken into consideration. Thus an estimate was made of the effect of conditions prevailing in the nest on the postnatal development of small rodents. This would appear to be important because the period of life in the nest is a specific prolongation of intrauterine life. The young continue to live in a tightly-packed group and although their nourishement is obtained in a different way, their existence continues to depend entirely on their mother. Also, the insulating properties of the nest and the presence of adults warming the young, ensures stable temperature conditions during postnatal development.

The reason for presenting and discussing the various parameters 
separately was that each of them was measured in a different way and forms a separate indicator of the changes taking place during postnatal development of the bank vole.

\section{A. PHYSIOLOGICAL AND BEHAVIOURAL ASPECTS OF BODY TEMPERATURE REGULATION}

\section{BODY TEMPERATURE AND RESISTANCE TO COOLING}

It is not easy to determine the body temperature of nestling voles, as measurements outside the nest cause underestimation, and data on nest temperature cannot be identified with the body temperature of the young living in it (Barnet t, 1956; Poczopko, 1969; M cManus, 1971). Therefore only direct measurement of the animals' body temperatures can indicate the thermal conditions during their development in the nest. When the body temperature was measured in the nests of Citeilus citellus (Gelineo \& Sokic, 1953) and laboratory mice (Barnett, 1956; Pichotka, 1971) it was noticed that it is characterized by some degree of stability. In some species of nesting birds it has also been observed that they maintain a certain constancy of body temperature, despite the fact that their thermoregulatory capacity is not yet formed (I rving \& $\mathrm{Krog}$, 1956). This would point to the existence of factors which ensure that a certain temperature level is maintained. It was decided to investigate the degree of efficiency with which these factors function in the bank vole. Measurements of body temperature were made for young animals on successive days of nest life and for purposes of comparison also for individuals which had already left the nest. In addition calculation was made of the resistance to cooling, that is, the capacity to counteract the heat effect of the habitat. The less body temperature is dependent on variations in ambient temperature, the higher the resistance to cooling of the given organism.

\subsection{Material and Methods}

The litters came from parents caught in spring, and were kept in cages measuring $40 \times 20 \times 15 \mathrm{~cm}$, the nest part of the cage being separated from the run. The bottom of the cage was lined with peat and the nest material was hay. For other details of breeding management see $B u c h a l c z y k$ (1970). Some litters were observed outdoors, where the animals were released in pairs into an enclosure measuring $4 \times 11 \mathrm{~m}$, and in which they were able to build nests of leaves and grasses in wooden How a I d (1949) boxes sunk in the earth.

Temperatures were measured with an electric thermometer (Type TE3, ElektroIaboratiet, Copenhagen) using $H 1$ and $F 6$ probes. The use of this thermometer allowed accurate measurement to $0.1^{\circ} \mathrm{C}$ within a few seconds, thus reducing the error due to handling. Temperature could be measured in regio axillaris (the 
armpit), with the $\mathrm{H} 1$ probe, and parallel measurement was made of rectal temperature (F6 probe) but only in the case of individuals over 7 days old, in which the probe was introduced to a depth of 1.5 to $3.5 \mathrm{~cm}$, depending on the size of the animal, thus bringing the probe tip to approximately mid-body. It was almost impossible to measure rectal temperature in individuals under 7 days old on account of their size and the different shape of the rectum from that in older animals, making it difficult to introduce the probe.

Body temperature was determined immediately after removing the animals from the nest. As a rule the measurements were carried out between 9 a.m. and 1 p.m. in order to avoid 24 -hour fluctuations in body temperature ( $\mathrm{K}$ a $\mathrm{y}$ s e $\mathrm{r}$ \& Heusner, 1967). The estimation of cooling rate was carried out in the following way: after measuring the initial body temperature the voles were kept singly or in whole litters in a glass chamber, with or without a nest, at an ambient temperatu:e of $5^{\circ} \mathrm{C}$ or $20^{\circ} \mathrm{C}$. When measuring cooling resistance in nests an artificial nest of cotton wool and cellulose tissue was used and was identical for all animals.

All measurements on the animals were made on consecutive days during their first month of life, without taking zero day into account. Age was determined in these and subsequent experiments by inspecting pregnant females daily, and when a litter was found during the morning inspection which had not been there the previous day it was assumed that the young had been born the previous evening or night and was one day old. When inspection time coincided with the birth phase, or when there were clear indications (young not yet fed, skin unclean) that birth had only just taken place, that day was taken as the time of birth and measurements began the following day. In this way all measurements of body temperature and cooling rate were made on animals which were not hungry. The reason for such procedure was the fact that thermoregulatory reaction in replete animals differs from that in hungry ones, as Baric (1953) has shown in the case of rats.

\subsection{Wavs of Measuring Body Temperature}

Rectal temperature is the most convenient value for expressing the characteristic temperature of a given species. However, measurement of internal body temperature in very small animals presents some difficulty when they are alive. It was difficult to introduce a probe per rectum in voles during the first week of life and as this must be done slowly, rendering it impossible to avoid underestimating body temperature. A series of tests was therefore made to show which place on the body surface gives a value close to internal body temperature and also allows rapid measurement. This place proved to be the armpit, regio axillaris. A series of temperature measurements were made in regio axillaris and per rectum (Table 1), which show that there is a high degree of agreement in the values obtained. The difference in temperature between these regions of the body is slight and in mean values does not exceed $0.2^{\circ} \mathrm{C}$.

To check the accuracy of the method several litters were masured in this way and then killed to obtain a true internal temperature; again 
the difference did not exceed $0.2^{\circ} \mathrm{C}$ (Table 1). It is interesting that the temperature in regio axillaris is either the same or slightly higher thain measured per rectum or straight inside. It was only in a few cases that the reverse relation were found, this having no connection with age (Table 1). It may therefore be taken that temperature measured in regio axillaris represents with sufficient accuracy the temperature inside the body of the individual examined.

\subsection{Postnatal Changes in Body Temperature}

A total of 1132 measurements was made on litters born and kept in normal breeding conditions indoors, with ambient temperature from

Table 1

Comparison of body temperature levels (mean $\pm S D$ ) measured per rectum and in regio axillaris, and in regio axillaris and straight inside.

The probe was inserted $1.5 \mathrm{~cm}$ into the rectum in the youngest animals, and up to $3.5 \mathrm{~cm}$ in the oldest ones. $\mathrm{n}$ indicates number of measurements.

\begin{tabular}{|c|c|c|c|c|}
\hline Age, days & Regio axillaris & Fectum & $\mathrm{n}$ & Body wt., g \\
\hline $\begin{array}{c}8 \\
9 \\
10 \\
11 \\
12 \\
13 \\
14 \\
15 \\
16 \\
17 \\
18 \\
19 \\
20 \\
21-30 \\
\text { Older } 1\end{array}$ & $\begin{array}{r}34.0 \pm 2.1 \\
34.3 \pm 1.7 \\
35.2 \pm 1.5 \\
35.3 \pm 1.4 \\
34.9 \pm 1.7 \\
35.8 \pm 1.1 \\
36.2 \pm 1.4 \\
36.6 \pm 1.2 \\
37.0 \pm 1.3 \\
37.3 \pm 1.5 \\
38.0 \pm 1.1 \\
38.8 \pm 0.8 \\
38.8 \pm 1.0 \\
38.8 \pm 0.4 \\
38.3 \pm 0.4\end{array}$ & $\begin{array}{l}33.9 \pm 1.9 \\
34.0 \pm 1.2 \\
35.0 \pm 1.6 \\
35.3 \pm 1.6 \\
35.0 \pm 1.4 \\
35.6 \pm 1.9 \\
36.0 \pm 1.7 \\
36.6 \pm 1.0 \\
36.9 \pm 1.1 \\
37.2 \pm 0.8 \\
37.8 \pm 0.9 \\
38.6 \pm 1.3 \\
38.7 \pm 0.9 \\
38.6 \pm 0.3 \\
38.2 \pm 0.5\end{array}$ & $\begin{array}{r}66 \\
44 \\
36 \\
42 \\
39 \\
36 \\
41 \\
32 \\
18 \\
26 \\
25 \\
24 \\
29 \\
149 \\
20\end{array}$ & $\begin{array}{r}4.4 \\
4.7 \\
5.2 \\
5.7 \\
6.1 \\
6.2 \\
6.9 \\
7.4 \\
7.7 \\
8.1 \\
8.6 \\
8.8 \\
9.4 \\
12.8 \\
16.7\end{array}$ \\
\hline Age, days & Regio axillaris & Straight inside & $n$ & Body wt., g \\
\hline $40-120$ & $39.1 \pm 0.6$ & $38.0 \pm 0.4$ & 17 & 15.4 \\
\hline
\end{tabular}

1 Measurements were made in March immediately after the animals had been caught in the forest, on individuals from 6 to 10 months old.

$18^{\circ}$ to $21^{\circ} \mathrm{C}\left(\mathrm{T}_{\mathrm{A20}}\right)$, and 379 measurements on litters born and kept at $4-7^{\circ} \mathrm{C}\left(\mathrm{T}_{\mathrm{A} 5}\right)$. In addition 38 measurements of body temperature were made on young bank voles which lived in outdoor enclosures.

\subsubsection{Laboratory Studies}

During the first 9 days of life body temperature in young voles from litters kept at $\mathrm{T}_{\mathrm{A} 20}$, was on an average $34.2^{\circ} \mathrm{C}$, but was $33.3^{\circ} \mathrm{C}$ for young 
from litters kept at $\mathrm{T}_{\mathrm{A} \mathbf{j}}$. The average level of body temperature showed considerable stability in both these groups (Fig. 1). Thus at $\mathrm{T}_{\mathrm{A} 20}$ the average body temperature on the fifth day of life is $0.6^{\circ}$ higher than on the third and seventh day (Table 2). Slightly greater differences are observed at $T_{A 5}$, when in young eight days old the body temperature was about $1^{\circ}$ higher than in younger and older animals (Table 2). Despite these differences the regression equation for young animals from 1 to 9 days old does not exhibit significant deviations with age in either group $\mathrm{T}_{\mathrm{A} 20}(r=-0.09, \mathrm{n}=502)$, or group $\mathrm{T}_{\mathrm{A} 5}(r=0.19, \mathrm{n}=167)$.

The constancy of body temperature on a level of $33-34^{\circ} \mathrm{C}$ exhibited by bank voles living in the nest during the first 9 days of life does not

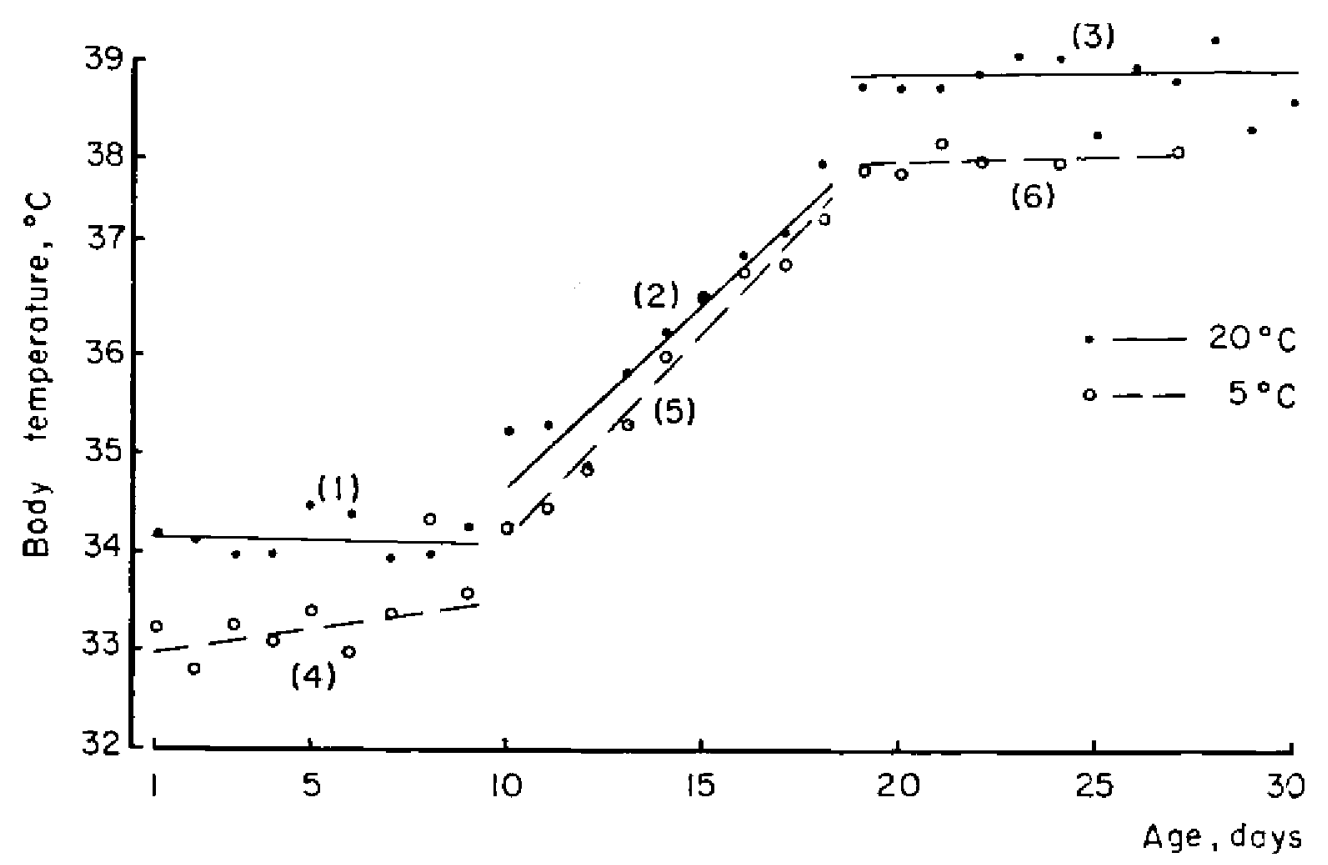

Fig. 1. Body temperature of the bank vole depending on age and ambient temperature.

(1) $\mathrm{Y}=34.1-0.007 x ; \mathrm{r}=-0.09, \mathrm{n}=502$

(2) $\mathrm{Y}=36.1+0.37 x ; r=+0.71, \mathrm{n}=295$

(3) $Y=38.8+0.009 x ; r=+0.13, n=202$

(4) $Y=33.3+0.09 x ; t=-0.19, n=167$

(5) $Y=35.8+0.41 x ; r=+0.65, n=168$

(6) $\mathrm{Y}=37.4-0.02 x ; r=-0.10, \mathrm{n}=64$

alter the fact that differences between the various individuals are far greater than in adults. This is indicated by the value of the standard deviation (Table 2).

Body temperature in bank voles from 10 to 18 days old presents a completely different picture. During this time there is a constant increase on successive days of life (Fig. 1). This increase is both even and 
rapid, as it is $0.4 \overline{5}^{\circ}$ per day at $T_{A 20}$ and $0.43^{\circ}$ per day at $T_{A 5}$. These relationships between body temperature and age are also confirmed by the calculated regression equations. It is characteristic here that variation in body temperature is less than in the previous period (Table 2), but is more clearly marked than in individuals over 19 days old.

The level of body temperature again becomes stable about the 19th cay of life and remains unchanged until the last day of observations. This stabilization takes place at an identical time in both groups $-\mathrm{T}_{\mathrm{A} . \mathrm{0}}$

Table 2

Changes with age in the body temperature of bank voles kept at different ambient temperatures.

Temperatures were recorded in regio axillaris immediately after removal from the nest. Mean values, standard deriations (SD) and coefficient of variations (CV) tre given. $n$ indicates number of measurements.

\begin{tabular}{|c|c|c|c|c|c|c|c|c|}
\hline \multirow{2}{*}{$\begin{array}{l}\text { Age, } \\
\text { days }\end{array}$} & \multicolumn{4}{|c|}{ At ambient temperature $18-21^{\circ} \mathrm{C}$} & \multicolumn{4}{|c|}{ At ambient temperature $4-7^{\circ} \mathrm{C}$} \\
\hline & Mean & $\mathrm{SD}$ & $\mathrm{cv}$ & $\mathbf{n}$ & Mean & SD & $\mathrm{CV}$ & $\mathrm{n}$ \\
\hline 1 & 34.2 & 1.9 & 5.6 & 69 & 33.2 & 1.5 & 4.5 & 23 \\
\hline 2 & 34.1 & 1.6 & 4.7 & 48 & 32.8 & 2.2 & 6.7 & 18 \\
\hline 3 & 33.9 & 2.7 & 8.0 & 57 & 33.2 & 1.7 & 5.1 & 18 \\
\hline 4 & 34.0 & 1.5 & 4.4 & 52 & 33.1 & 1.6 & 4.8 & 16 \\
\hline 5 & 34.5 & 1.4 & 4.1 & 52 & 33.4 & 1.3 & 3.9 & 19 \\
\hline 6 & 34.4 & 1.9 & 5.5 & 64 & 33.0 & 1.7 & 5.2 & 17 \\
\hline 7 & 33.9 & 1.6 & 4.7 & 50 & 33.4 & 1.2 & 3.6 & 22 \\
\hline 8 & 34.0 & 2.1 & 6.2 & 66 & 34.3 & 0.9 & 2.6 & 14 \\
\hline $\mathrm{g}$ & 34.3 & 1.7 & 5.0 & 44 & 33.6 & 1.3 & 3.9 & 23 \\
\hline 10 & 35.2 & 1.5 & 4.3 & 36 & 34.2 & 1.9 & 5.6 & 21 \\
\hline 11 & 35.3 & 1.4 & 4.0 & 42 & 34.4 & 1.6 & 4.7 & 21 \\
\hline 12 & 34.9 & 1.7 & 4.9 & 39 & 34.9 & 1. I & 3.2 & 13 \\
\hline 13 & $\mathbf{3 5} .8$ & 1.1 & 3.1 & 36 & 35,3 & 1.1 & 3.1 & 16 \\
\hline 14 & 36.2 & 1.4 & 3.9 & 41 & 36.0 & 0.5 & 1.4 & 14 \\
\hline 15 & 36.6 & 1.2 & 3.3 & 32 & 36.6 & 1.1 & $3, \theta$ & 24 \\
\hline 16 & 37.0 & 1.3 & 3.5 & 18 & 36.9 & 1.1 & 3.0 & 21 \\
\hline 17 & 37.3 & 1.5 & 4.0 & 26 & 37.0 & 0.7 & 1.9 & 24 \\
\hline 18 & 38.0 & 1.1 & 2.9 & 25 & 37.4 & 0.7 & 1.9 & 14 \\
\hline 19 & 38.8 & 0.8 & 2.1 & 24 & 37.9 & 0.8 & 2.1 & 15 \\
\hline 20 & 38.8 & 1.0 & 2.6 & 29 & 37.9 & 0.4 & 1.1 & 12 \\
\hline 21 & 38.8 & 0.7 & 1.8 & 22 & 38.2 & 0.7 & 1.8 & 10 \\
\hline 22 & 38.9 & 0.5 & 1.3 & 20 & & & & \\
\hline 23 & 39.1 & 0.5 & 1.3 & 17 & & & & \\
\hline 24 & 39.0 & 0.5 & 1.3 & 14 & 37.7 & 0.6 & 1.6 & 10 \\
\hline 25 & 38.3 & 0.3 & 0.8 & 9 & & & & \\
\hline 26 & 38.9 & 1.0 & 2.6 & 20 & & & & \\
\hline 27 & 38.8 & 0.4 & 1.0 & 14 & 38.1 & 1.0 & 2.6 & 17 \\
\hline 28 & 39.3 & 0.6 & 1.5 & 11 & & & & \\
\hline 29 & 38.3 & 0.5 & 1.3 & 8 & & & & \\
\hline 30 & 38.6 & 0.7 & 1.8 & $1 \tilde{4}$ & & & & \\
\hline
\end{tabular}

Ind $\mathrm{T}_{\mathrm{A5}}$ - but at a different level of body temperature. At $\mathrm{T}_{\mathrm{A} 20}$ it equals $38.8^{\circ} \mathrm{C}$ and at $\mathrm{T}_{\mathrm{A}}$ it is $38.0^{\circ}$. This difference is very similar to that in ndividuals from 1 to 9 days old. However, the difference between the youngest voles is not statistically significant, but it is highly significant $n$ animals over 19 days old $(P<0.01)$ 


\subsubsection{Outdoor Enclosure Studies}

Data collected on litters living in outdoor enclosures, although few in number, are important because the environment is closer to that found in nature. Individuals under 10 days old have a body temperature not lower than $30^{\circ} \mathrm{C}$, despite the fact that the enclosed female sometimes leaves the nest for a long period (Table 3 ). In two of the litters examined the body temperature of animals 10 to 12 days old was clearly higher than in younger individuals. There can therefore be no doubt that

Table 3

Body temperature of nestling bank roles from litters living in nest in outdour enclosures. The nests were situated in boxes sunk into the soil.

\begin{tabular}{|c|c|c|c|c|c|c|c|}
\hline \multirow{2}{*}{$\begin{array}{l}\text { Age, } \\
\text { days } \\
\qquad 2\end{array}$} & \multicolumn{3}{|c|}{$\begin{array}{l}\text { Body tempe- } \\
\text { rature, }{ }^{\circ} \mathrm{C}\end{array}$} & \multirow{2}{*}{$\frac{\text { Mean, }{ }^{\circ} \mathrm{C}}{33.4}$} & \multirow{2}{*}{$\begin{array}{c}\text { Air tempe- } \\
\text { rature, }{ }^{\circ} \mathrm{C} \\
6.1\end{array}$} & \multirow{2}{*}{\multicolumn{2}{|c|}{$\begin{array}{l}\text { The mesurements } \\
\text { were made after: } \\
\text { The female left the nest for } \\
25 \text { minutes }\end{array}$}} \\
\hline & 33.0 & 33.7 & 33.5 & & & & \\
\hline 3 & $\begin{array}{l}30.0 \\
30.0\end{array}$ & $\begin{array}{l}31.2 \\
32.4\end{array}$ & $\begin{array}{l}30.6 \\
30.4\end{array}$ & 30.8 & 7.0 & $\begin{array}{l}\text { The female left the nest } \\
\text { for } 33 \text { minutes }\end{array}$ & \\
\hline 4 & $\begin{array}{l}34.2 \\
34.0\end{array}$ & 33.8 & 33.6 & 33.9 & 10.5 & $\begin{array}{l}\text { Immediately after the female } \\
\text { left the nest }\end{array}$ & had \\
\hline 5 & 32.9 & 33.2 & $33 ; 2$ & 33.1 & 8.3 & $\begin{array}{l}\text { The female remained outside } \\
\text { nest for at least } 30 \text { minutes }\end{array}$ & ttee \\
\hline 7 & $\begin{array}{l}31,4 \\
31,4\end{array}$ & $\begin{array}{l}31.7 \\
30.9\end{array}$ & 31.7 & $3: 4$ & 5.2 & $\ldots$ & \\
\hline 8 & 33.8; & 33.8 & 33.5 & 33.7 & 11.7 & $\begin{array}{l}\text { The female remained outside } \\
\text { nest for at least } 25 \text { minutes }\end{array}$ & tree \\
\hline 8 & $\begin{array}{l}34.6 \\
34.0\end{array}$ & 34.8 & 35.0 & 34.6 & 4.0 & $\begin{array}{l}\text { The female left the nest } \\
38 \text { minutes }\end{array}$ & for \\
\hline 10 & $\begin{array}{l}35.4 \\
35.1\end{array}$ & 35.0 & 34,5 & 35.0 & 2.0 & $\begin{array}{l}\text { Immediately after the fomale } \\
\text { left the nest }\end{array}$ & had \\
\hline 12 & $\begin{array}{l}36.2 \\
36.0\end{array}$ & 35.4 & 35.5 & 35.8 & 9.0 & $\begin{array}{l}\text { Immediately after the female } \\
\text { left the nest }\end{array}$ & hat \\
\hline
\end{tabular}

under such conditions the body temperature of nesting bank voles is high and is somewhat stable.

\subsection{Development of Resistance to Cooling}

By measuring the rate of reduction in body temperature under condition of physiological cold it is possible to estimate the reverse of resistance to cooling, that is cooling rate $(C)$. The rapidity of reduction in hody temperature was calculated as an agreed index by means of the following equation: $\quad C=\left(T_{s}-T_{f}\right) \times 100: t$

When:

$T_{s}$ - initial value of body temperature

$T_{f}$ - final value of body temperature

$t$ - time in minutes. 
Voles out of the nest, $T_{A 22}$. At this ambient temperature index $C$ on the first days of life is almost 50 (Table 4), but decreases fairly rapidly. At the beginning of the second week of life this index is reduced by almost half (Fig. 2). Heat loss rate estimated in this way is only slightly higher in separated individuals than in those kept together in whole litters; the difference is not significant.

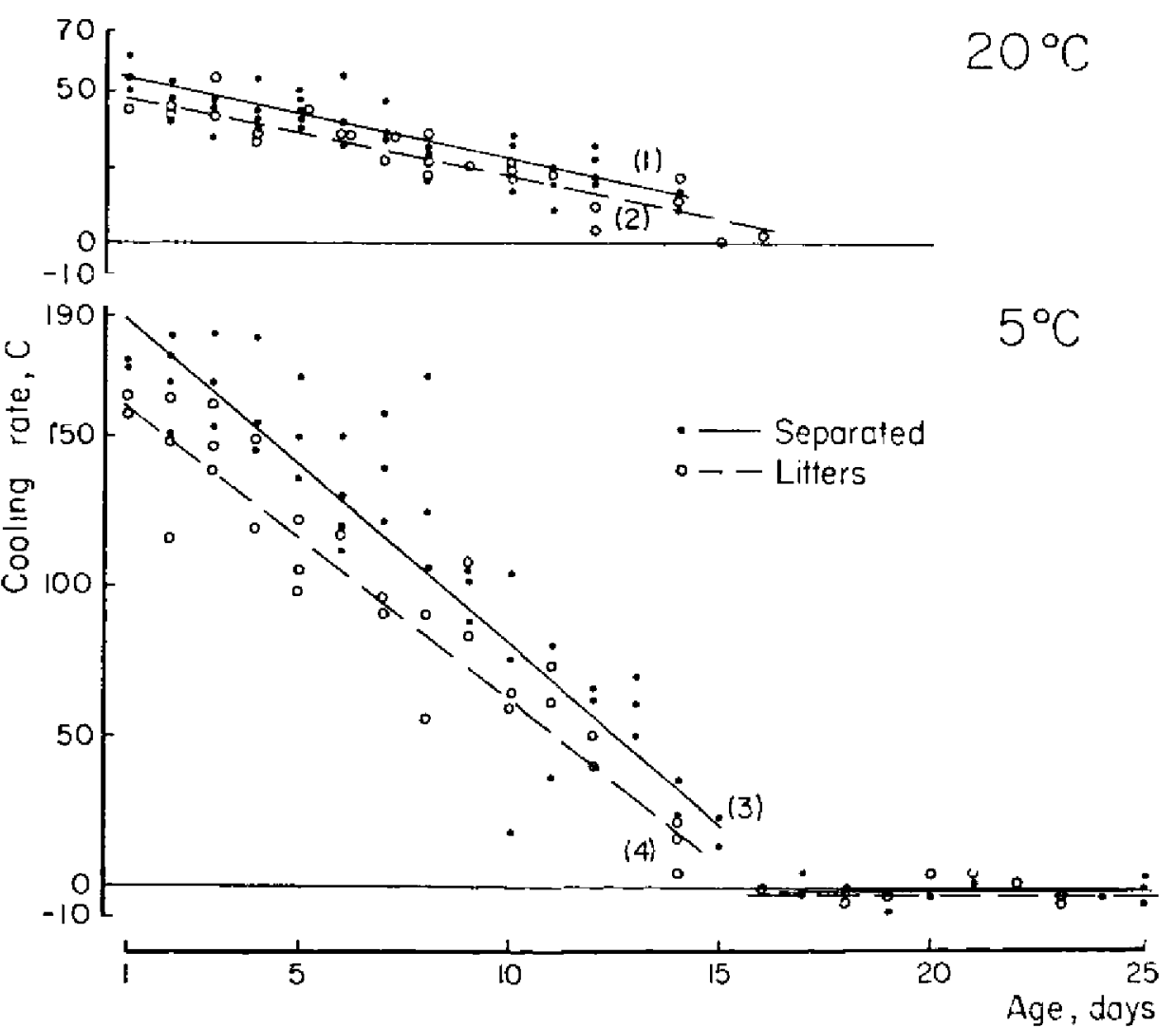

Fig. 2. Changes with age in the cooling rate index for the bank role due to varying ambient temperature.

Fach dot indicates mean value for the litter irrespective of whether the young were kept together during the experiment, or were separated.

(1) $\mathrm{Y}=37.2-2.76 \mathrm{x} ; r=-0.64, \mathrm{n}=13$

(2) $Y=29.8-2.78 x ; r=-0.69, n=17$

(3) $\mathrm{Y}=119.2-11.24 x ; r=0.86, \mathrm{n}=24$

(4) $\mathrm{Y}=94.3-10.39 x ; r=-0.87, \mathrm{n}=27$

Voles out of the nest, $T_{\mathbf{A 5}}$. Under these conditions reduction in body temperature during the course of the experiments was very great. On the first days of life in animals kept singly index $C$ is three or more times higher than at a temperature of $20^{\circ} \mathrm{C}$ (Table 4).

The resistance to cooling of voles subjected to the effect of cold in 
whole litters is slightly greater than was the case with separated voles: nevertheless in both cases cooling rate during the first week of life is rapid. It is subject only to a slight reduction during this period, which can be explained chiefly by an increase in the body mass of the individuals examined. It was not until the second week of life that a rapid increase in resistance to cooling is observed in bank voles. In the thirc week of life the capacity to resist the cooling effect of the habitat is

Table 4

Changes of cooling rate index (C) of nestling roles during their first two weeks of life, depending on ambient conditions.

$C$ shows a conventional value of body temperature decrease during a time unit. Number of litters used for the mesurcments is given in brackets.

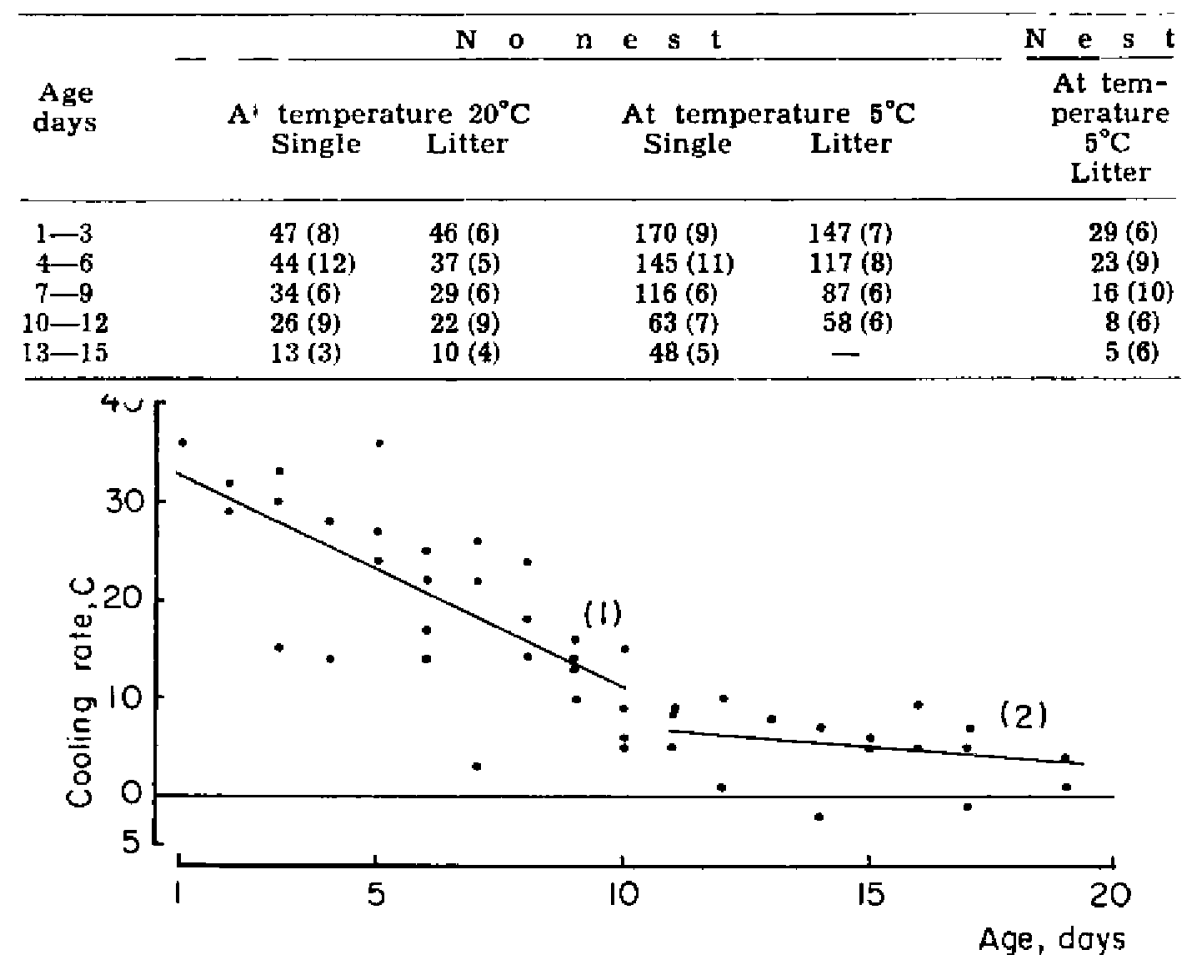

Fig. 3. Changes in cooling rate index for litters of bank roles in their nests, with ambient temperature of $5^{\circ} \mathrm{C}$. For explanation of symbols see Fig. 2 ,

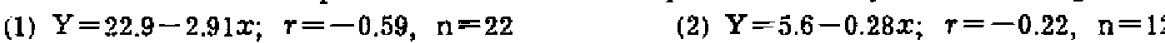

essentially established, proof of which is that the index of cooling is close to zero (Fig. 2).

Voles in the nest, $\mathrm{T}_{\mathrm{A} \text { s. }}$. Under such conditions cooling rate was the lowest in comparison with the previous experiments. During the first week of life it varies within limits of 30 (Fig. 3) and therefore forms 
only slightly more than half the true value for measurements outside the nest at $\mathrm{T}_{\mathrm{A} \text { yn }}$. If results obtained with $\mathrm{T}_{\mathrm{A} ;}$ are compared it becomes strikingly clear that the lack of a nest causes six times the increase in cooling rate in the youngest individuals. This very sharp differentiation is maintained through the first 10 days of life and it is not until the end of the second week of life that this difference decreases (Table 4).

The reaction to cold in animals over two weeks old is characteristic here. It has been observed that the lack of a nest increases their activity and/or causes shivering, which consequently causes a rise in body temperature in comparison with the value at the start of the experiment, and thus index $C$ sometimes has a negative value. Voles in the nest, on the other hand, would not appear to increase their activity, as may be seen from the resultant measurements of body temperature, when $T_{i}$ is rarely greater than $T_{s}$.

\subsection{Discussion}

Measuring body temperature in the bank vole on successive days of its first month of life made it possible to assess not only how this character is formed during the period of life in the nest, but also during the period when the young leave the nest and begin independent life. There are unfortunately no reliable data on the length of time the voles remain in the nest. when they begin to leave it and when they begin a fully independent life. Petrov \& Airapetjanc (1961) maintain that under natural conditions the young begin to leave the nest at the age of 14-15 days, but Bujalska, Andrzejewski \& Petrusew ic $z$ (1968) assumed that bank voles may be caught at the age of about 21 days, since they leave the nest at this time. If we take this sccond period as correct it coincides with the period during which adult body temperatures is established. It would. however, appear that young bank voles periodically begin to leave the nest before becoining completely independent, and this assumption is confirmed by the observations made by Petrov \& Airapetjanc (1961). However, irrespective of which day of life bank voles do in fact become independent, three separate stages of stabilisation of body temperature can be distinguished. The first of these lasts up to the 9th day of life, the second between the 10th and 18th day and the third begins on the 19th day of life. It must be remembered here that the duration of the different slages in development of body temperature coincide exactly with the times of development of the animals' coat ( $\mathrm{M}$ a $\mathrm{z}$ a $\mathrm{k}, 1962$ ).

The bank vole, like many other species of mammals, is an waltricial " species in which poikilothermic conditions extend well after birth. The 
opposite to such animals are sprecocial« species which thermoregulation at birth does not differ from that of adults. Although both these concepts, which were in fact introduced for birds, have been used in physiology for over a century, they are now considered as expressing extreme forms among homeothermal animals. The increasing amount of knowledge obtained on postnatal development of birds and mammals, although not denying the existence of the differentiation referred to, shows that there are many intermediate types (see reviews by Gelineo, 1959; Barnett \& Mount, 1967; Dawson \& Hudson, 1970; Poczopko, 1973). Species with well-developed heat production mechanisms at birth, heat loss regulators and feedback control maintain constant body temperature. Incomplete formation during the period of foetal life of any one of the foregoing links results in the body temperature of the animal being more or less subject to the effect of ambient temperature. The degree to which it is dependent has been examined experimentally, chiefly in laboratory species such as mice (e.g. Barnet t, 1956; Lagerspet $\mathrm{z}, 1962$ ), rats (e.g. Capek et al., 1956; Poczopko, 1961) and domestic animals: pigs (Mount, 1968), rabbits (Poczopko, 1969).

Information on mammals living under natural conditions provides only the rough outlines of the situation (Gelineo \& Sokić, 1953; Morrison, Ryser \& Strecker, 1954; Ostbye, 1965; Hissa, 1968; Gębczyński, 1970; M c Manus, 1971). Morrison et al. (1954) showed that Clethrionomys rutilus at the age of $7-14$ days has a body temperature in the nest $3^{\circ} \mathrm{C}$ lower than that of individuals $23-34$ days old. The collection of data on body temperature during the animals' life in the nest involes the destruction of the nest, even if only partially. This disturbs the normal living conditions of the litter and may alter the behaviour of the parents ( $B$ a $r n$ e $t, 1973$ ). Therefore in order to reduce to a minimum the effect of such measurements on the development of the study individuals it is essential to use a large number of litters, to be examined as seldom as possible. As the number of bank vole litters examined in our case was well over 200 this condition was to a certain extent satisfied.

The level of body temperature in the bank vole during the first 9 days of life is about $4.5^{\circ}$ lower than in adults. In addition the range of variation, as shown by the coefficient of variation (Table 1), is far higher. It is nevertheless a fact that the level of this temperature is fairly constant. Somewhat similar thermal conditions are characteristic of the laboratory rat (Poczopko, 1961) and also of laboratory mice ( $\mathrm{Pi}$ chot ka, 1971) in which body temperature is $32.5^{\circ} \mathrm{C}$ on the first day of life, and $33.5-33.8^{\circ} \mathrm{C}$ on the second, fourth and fifth. In older in- 
dividuals it rises to reach the adult level between the 15 th and 18th day of life. In young Meriones unguiculatus in the laboratory, bodv temperature recorded immediately after removal from the nest is also fairly constant and even higher, the average being $35^{\circ} \mathrm{C}$ ( $\mathrm{M} \mathrm{c} \mathrm{M} \mathrm{a} \mathrm{n} \mathrm{u} \mathrm{s,} 1971$ ).

As studies were carried out at two different $\mathrm{T}_{\mathrm{A}}$ it was possible to ascertain that at $5^{\circ} \mathrm{C}$ the body temperature of bank voles $1-9$ days old was about $1^{\circ}$ lower than in voles kept in a temperature of $20^{\circ} \mathrm{C}$. The considerable difference in ambient temperature did not disturb the functioning of the mechanisms which ensure constant body temperature in young voles, but merely caused a slight drop in its mean value. Measurements of this index in litters kept out of doors also confirm the results obtained. There are thus factors which compensate for the effect of ambient temperature and create a certain stability of thermal conditions for the growth and development of the young voles. Among such factors the most important is maternal care, expressed inter alia in nest-building behaviour, the nest being more solidly built when ambient temperature is lower. Another form of maternal care is expressed in the bank vole by the mother warming her young with her own body (for a detailed discussion of different forms of maternal care see section 3 ).

The next factor to be of importance in maintaining constancy of body temperature in the youngest bank voles is their huddling together in a close-packed group. The importance of huddling together in a group, and also living in the nest, is shown by measurements of the cooling rate. It is lower in individuals remaining in the litter, as can be seen particularly clearly in experiments at an ambient temperature of $5^{\circ} \mathrm{C}$. However, no significant differences were found in the cooling rate for small ( $2-3$ voles) and large litters ( $4-6$ individuals together). Litter size is nevertheless an important factor, as is indirectly shown by the greater capacity for survival in large than in small litters ( $R$ ys zkowski \& Truszkowski, 1970).

We can only assume the answers to the question as to why body temperature is $33-34^{\circ} \mathrm{C}$ in bank voles Iess than 10 days old. It is certainly the result of all those factors which maintain its stability, of these the most important would appear to be the fact that surface body temperature of an adult bank vole is $34 \pm 2^{\circ} \mathrm{C}$ for different ambient conditions (Cotton \& Griffith, 1967), hence litters are warmed by the mother to this temperature.

Bank voles 10 to 18 days old are characterized by completely different body temperature properties than in the earlier period of life. At this age their body temperature rises by almost $0.5^{\circ} \mathrm{C}$ daily. Therefore it cannot be said that during this period in the nest bank voles have 
a constant level of body temperature, but rather that they are characterized by a constant rate of increase in this temperature until it reaches adult level.

A similar phenomenon of abrupt increase in body temperature in yourg animals a few days after birth was found by Pichot $\mathrm{ka}$ (1971) in laboratory mice, and by Shilov (1968) in birds - Muscicapı hypoleuca and Parus major. In Meriones unguiculatus resistance to cooling develops gradually between the 12th and 19 th day of life (McMauns, 1971). In all these species, as in the bank vole, body temperature is fairly stable during the initial period, although lower than in adults, and this is followed by a period of rapid increase up to the adult level. It is possible that this type of development is connected with the extremely small body dimensions, since all the species referred to are small animals and do not weigh more than $15 \mathrm{~g}$ during the period of their lives in which this rise in temperature takes place. In larger mammals such as rabbits (Poczopko, 1969) or edible dormice (G ębczynski, 1970), although the young have a lower body temperature after birth than adult temperature, it increases gradually on the successive days of their life. Therefore cnly two periods can be distinguished in the rabbit and the dormouse: increase in body temperature to the adult level and then its stabilisation. In laboratory mice and the bank vole, and also in the two species of birds, there are three such periods; namely, in addition to the two periods mentioned above, there is a preceding period of postnatal establishment with a stable temperature on a level lower than that of adults.

All the data presented above show that the bank vole reaches a state of constant body temperature after passing through three successive phases of development of body temperature. These phases are closely connected with individual growth and development and in addition depend of the habitat factors formed chiefly by parental care.

\section{THE TFIERMOREGULATORY SIGNIFICANCE OF MATERNAL CARE}

Miaternal (=parental) care constitutes one of the important, although insufficiently investigated, forms of social behaviour. The mother, or both parents, and sometimes other members of the group, may contribute to such manifestation of activity as building, protection and defence of the nest, licking, grooming, playing and direct contact with olfspring. For young animals, also characterized by their own specifis reactions, maternal care is not only an essental condition of their existence but it also provides the possibility of gradual adaptation to the habitat before attainment of independent life. The specificity of maternal care 
patterns is sufficiently great in different species of mammals to make generalizations impossible ( $\mathrm{R}$ heingold, 1963), but this phenomenon has been far more thoroughly examined in a second group of homeothermic animals - birds (Kendeigh, 1952) and its importance fully realized in consideration of postnatal development (D a w s on \& $\mathrm{H} \mathrm{ud}$ s on, 1970). Nevertheless the similarity due to the degree of physiological development of young mammals during the postnatal period justifies comparisons of maternal behaviour. Thus, although there were no data of this kind available for the bank vole, it was possible to seek analogies with other small rodents.

After building the nest, the chief form of care is the presence of the mother or both parents, and sometimes also of other members of the

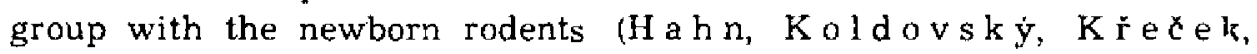
Martinek \& Vacek, 1961; King, 1963; Rosenblatt \& Lehrmann, 1963; Ponugaeva, 1960; Pegelmann, 1966; Hi11, 1972). As the length of time spent with the young animals can be treated quantitatively, measurements of this kind of behaviour were made for the bank vole.

\subsection{Material and Methods}

Observations were made of 10 litters of bank voles kept in the laboratory at a temperature of approx. $19^{\circ} \mathrm{C}$. The female was kept together with the male in cages measuring $40 \times 20 \times 15 \mathrm{~cm}$. The nest containing the young was situated in a separate part of the cage $(20 \times 20 \times 15 \mathrm{~cm})$ into which there were two entrances from the part in which food and water were supplied. The cage was aiways kept lighted, so that it was possible to observe the number of times the male or female emerged from the nest part, and to record the length of the time spent outside it.

In the enclosure $(4 \times 11 \mathrm{~m})$ observations were made jointly of 6 voles with their young, on consecutive days of the latter's development. These females built nests in Howard boxes sunk into the soil. To start with, it must be emphasised that the males always lived separately in the enclosure and were never observed to stay with the young, which were cared for by the mother only. Neither the construction of the nest part of the cage nor the Howard box allowed confirmation of the assumption that the adults inside them always stayed in the nest with the young. However, breeding practice and the fact that the lactating female, with double the normal food requirements, remained twice as long as in the run of the cage juslify the assumption.

The observer, using a stopwatch, recorded each exit and entrance of the adults, whether this was into the nest under laboratory conditions or else into the tunnel leading into the nest in the case of the enclosure. Observations were made both day and night in the laboratory, but during the day only in the enclosure. Each male was marked by cutting off the ends of the hair on neck and rump.

\section{3,2 Laboratory Observations}

As observations were made of families with offspring from 2 to 14 days old, comparison was made of the time spent by the female and the male 
outside the nest depending of the day of life of the young, but no significant differences were found. The females remained in the nest on an average for $84 \%$ of the whole 24-hour period (Table 5). The remaining period, lasting on an average almost 4 hours, was spent by

Table 5

Periods parent bank voles spent in nests with their offspring

\begin{tabular}{|c|c|c|c|}
\hline \multirow{2}{*}{ Item } & \multicolumn{2}{|c|}{ Laboratory } & \multirow{2}{*}{$\begin{array}{c}\text { Enclosure } \\
\text { Female }\end{array}$} \\
\hline & Female & Male & \\
\hline Number of observations & 10 & 10 & 6 \\
\hline \multicolumn{4}{|l|}{ Daily stay in the nest: } \\
\hline $\begin{array}{l}\text { Mean, per cent } \\
\text { hours, minutes }\end{array}$ & $20 \mathrm{~h}^{84} 10^{\prime}$ & $22 \mathrm{~h}^{93} 19^{\prime}$ & $\begin{array}{l}76 \\
18 h^{\prime} 14^{\prime} 1\end{array}$ \\
\hline $\begin{array}{l}\text { Minimum, per cent } \\
\text { hours, minutes }\end{array}$ & 18 h $48^{\prime}$ & $\begin{array}{c}88 \\
21 h^{\prime}\end{array}$ & $\begin{array}{c}64 \\
15 h^{\prime} 21^{\prime} ?\end{array}$ \\
\hline $\begin{array}{l}\text { Maximum, per cent } \\
\text { hours, minutes }\end{array}$ & $21 \stackrel{88}{h} 7^{\prime}$ & $\begin{array}{c}96 \\
23 \mathrm{~h}^{\prime}\end{array}$ & 20 h $53^{\prime 2}$ \\
\hline
\end{tabular}

1 Observations were made only during the daytime and lasted for and average 7 hours, the results obtained being extrapolated for a whole 24-hour period. "Values calculated for the actual duration of observations.

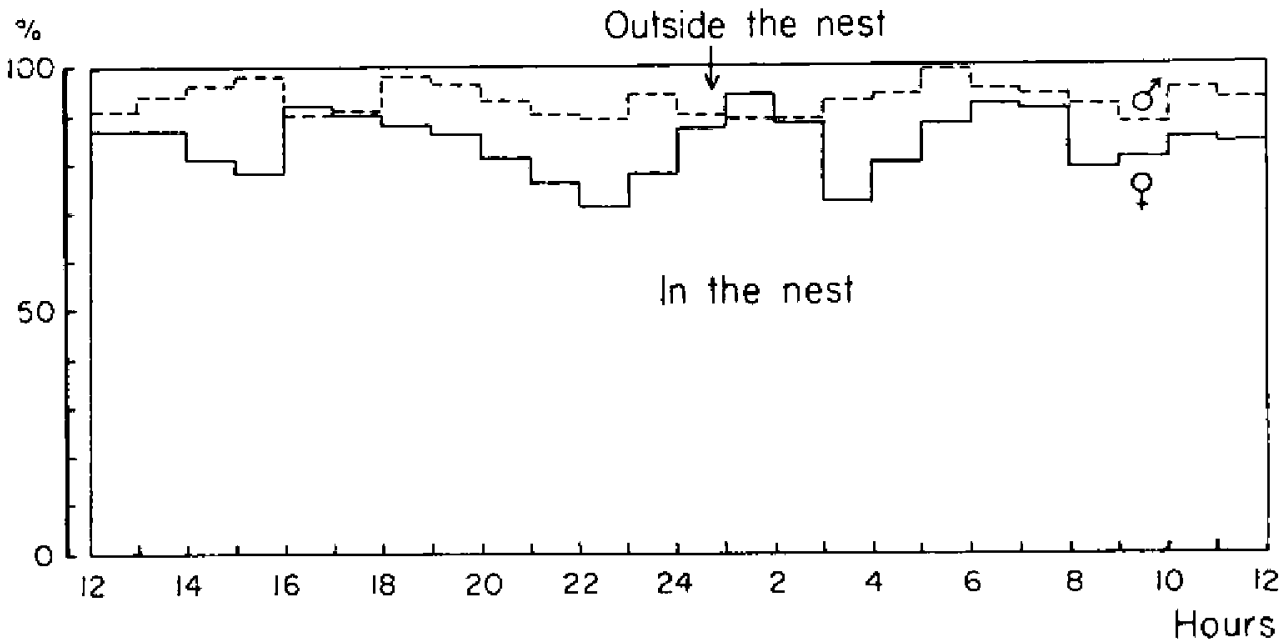

Fig. 4. Percentage distribution of time spent inside and outside the nest by a female and a male during the first two weeks of life of their offspring.

the female outside the nest. Males emerge from the nest far less often and for a shorter time. The average time of their activity was shorter than 2 hours (Table 5). It is a striking fact here that it is only in a few cases that the male was observed outside the nest during the same time as the female. It also proved possible to establish that then the female 
was in the run together with the male, the former often behaved agressively towards the male, forcing him to return to the nest.

These differences between males and females, and also the 24-hour differentiation of activity outside the nest, are illustrated in Fig. 4. It can be seen that during the day there are four periods of intensified activity outside the nest in the case of the female, while the activity of the male is more even. As in the case of Rattus norvegicus, females with young exhibit a specific daily rhythm (A der \& Grota, 1970).

\subsection{Observations in the Outdoor Enclosure}

The length of time spent by females away from their offspring under the conditions in the enclosure differs from those in the laboratory

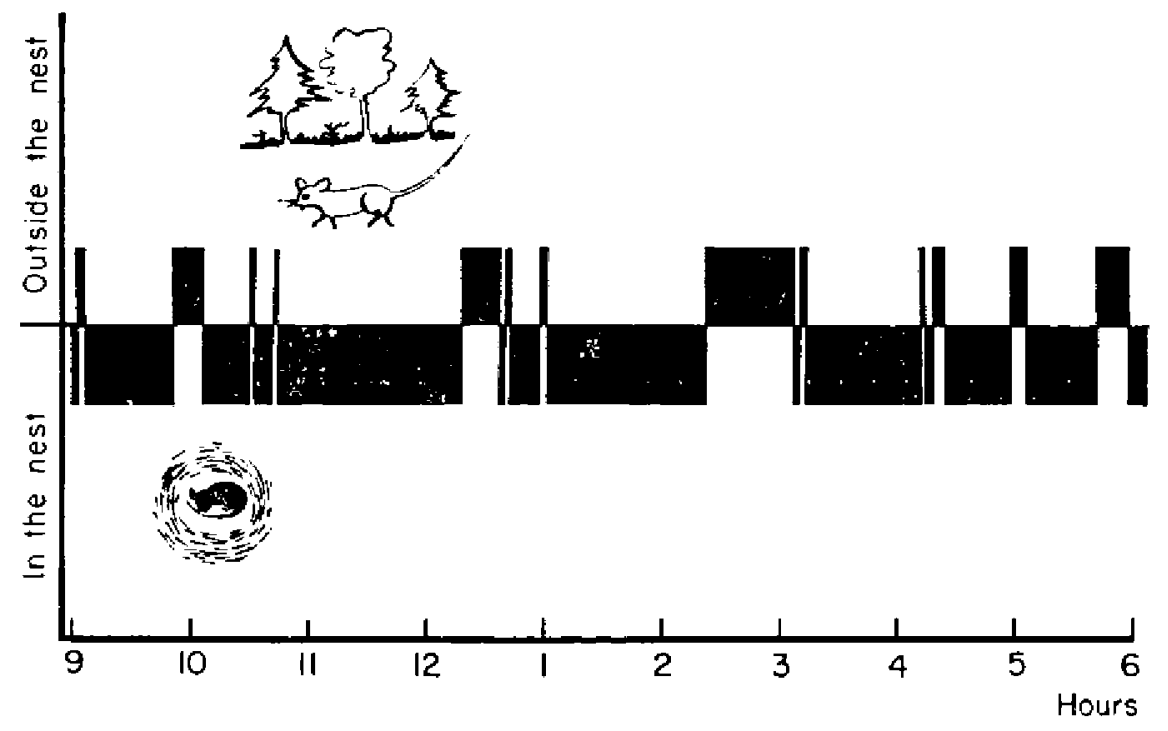

Fig. 5. Periods spent in and outside the nest by one of the females rearing 4 young aged 6 days under semi-natural conditions (the enclosure). The observations were made continuously for 9 hours and 10 minutes.

(Table 5). By extrapolating data obtained for the enclosures to a 24-hour period it was calculated that the females leave their young for about 6 hours.

The activity pattern of females kept in enclosures has been described by taking a female observed for 9 hours 10 minutes as an example (Fig. 5). During this period the female remained with the young in the nest for a total time of 6 hours and 57 minutes, and outside the nest (searching for food and wandering over the area of the enclosure), 
for 2 hours and 13 minutes. The longest times spent outside the nest were 45 and 36 minutes, the other periods being far shorter and not $\in$ xceeding 14 minutes. In addition, the female was observed to emerge four times from the nest for periods of less than 1 minute 1.

\subsection{Discussion}

The observations showed that the activity of females caring for their offspring is different in cages from that in enclosures, and that in enclosures males do not participate in rearing the young. The longer period for which young are left without direct care in the enclosure does not cause a significant change in the temperature condition of their development. This is probably due to the fact that with cold conditions the female builds a larger nest with thicker walls ( $G$ el in e o \& Geline o, 1952; Pegel man, 1966), and consequently the cooling process takes place more slowly in young left without maternal care. This assumption has been confirmed by measurements of the body temperature in offspring of females kept under different temperature conditions (cf. section 2).

The capacity for building different nests depending on ambient temperature has been assessed quantitatively not only in the laboratory species: the rat ( $\mathrm{K}$ inder, 1927) and mouse ( $\mathrm{B}$ a $\mathrm{rne} t \mathrm{t}$, 1956), but also in wild Peromyscus (L a y ne, 1969). Nest-building behaviour resulting in an organized nest arises shortly before parturition and in the rat continues for the first two weeks of litter care, then declines and disappears (Rosenblatt \& Lehrman, 1963). In the bank vole also the nest differs in respect of size and form depending on the temperature in the laboratory. Observations in the forest show that the female bank vole builds a solid nest for the young (B B a lska \& Rajska, 1972; Truszkowski, 1974; author's own observations). This capacity for constructing nests appropriate to actual needs is undoubtedly of prime importance in protecting the young voles from cold during the first two weeks of their life.

Another form of maternal care is the female herself warming her young, to which Gelineo \& Gelineo (1950) and Gelineo \& S o kic (1953) have previously drawn attention. Observation of lactating female activity in the laboratory show that they spend about 20 hours out of the 24 in the nest (cf. Górecki, 1968). Preliminary measurements made directly outdoors showed that the bank vole

1 At the same time it was observed that some females on emerging from the corridor leading to the nest part always concealed the entrance, using leaves fallen from trees and sometimes grass blades lying close by. 
remain only 4 to 6 hours daily outside the nest ( $\mathrm{K}$ a r u lin et al., 1973). In other species of rodents also, e.g., those belonging to the genus Peromyscus, the mother spends over 20 hours each day with her young (K ing, 1963). Although H i I (1972) found in the case of Peromyscus leucopus noveboracensis that the amount of maternal care depends on experimental conditions, and that mothers in forests tended to spend more time away from their young than the laboratory mothers, it was nevertheless observed that young bank voles are warmed by the mother over long periods. Measurements of body temperature confirm that the exit of the female does not mean that there is an immediate decrease in the body temperature of the young, even at low ambient temperatures. This refutes Hill's opinion (1972) that young Peromyscus leucopus are maintained at a stable thermal status only when in the company of their mother.

Thus the period spent by females in the nest with their young is even more variable than could been expected from laboratory observation. However, it seems certain that the stable level of body temperature in young bank voles essential to their development, is ensured by the presence of the mother and by the insulating properties of the nest. In addition young bank voles are able to produce a certain amount of warmth themselves when subjected to cold, thus contributing to maintaining their own homeothermal state.

\section{METABOLIC RATE AT DIFFERENT AGES AND AT DIFFERENT AMBIENT TEMPERATURES}

Previous studies of small rodents, chiefly laboratory rats and mice, have not shown unequivocally that they already possess the capacity for intensifying metabolism as a response to cold during the first few days after birth. Some authors (Pembrey, 1895; Leichtentritt, 1919; Antoschkina, 1939; Hill, 1947; Fairfield, 1948) state that rats are poikilothermal at birth, not showing evidence of chemical regulation until one or two weeks of age. Pincus, Sterne \& Enzmann (1933), however, showed that day-old laboratory mice have a body temperature slightly higher than their surroundings at temperatures of 15 to $35^{\circ} \mathrm{C}$. Measurements made on rats (G eline o \& Geline o, 1951; B arić, 1953) also confirmed the existence of certain forms of chemical thermoregulation. Metabolism intensifies as a reaction to the effect of cold even on the first day of life in the rat (T a y lor, 1960; Várnai \& Donhoffer, 1970). This does not of course mean that under conditions of lasting cold the newborn rodents are capable of maintaining a constant body temperature. In the first place they have no mechanisms for heat conservation, since vasomotor reactions in the 


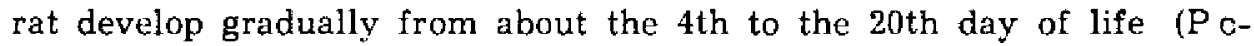
$\mathrm{czopko}, 1961)$, neither is there any physical thermoregulation at all in newborn laboratory mice ( $\mathrm{Pi} \mathrm{chotk} \mathrm{a}, 1971$ ).

The development of chemical thermoregulation in the bank vole was studied by measuring the oxygen consumption of litters of 1 to 6 individuals. This made it possible to estimate the metabolic reactions of growing rodents to the effect of both physiological cold and heat. The assumption was made that litters form a certain functional unity and only the indices proper to them reflect the living conditions in the nest. These studies provide information on the rate of development of thermoregulatory functions and the metabolic rate and value of energy requirements in different periods of the first month of life of the bank vole.

\subsection{Material and Methods}

Oxygen consumption was measured in a closed type respirometer as described by $\mathrm{Kalabukh} \mathrm{ov}$ (1951). Jars of 300 to $1000 \mathrm{ml}$ capacity, depending on the age of the voles and litter size, were used as respiration chambers; the floor surface allowed the dispersal of individuals from the litters examined.

Each measurement of oxygen consumption was made as soon as possible after removing the litter from the nest. The voles were taken from the nest directly to the respiration chamber and measurement started immediately. Body weight was determined at the end of the measurements. In practice the time lapse from remoral of the litter to the start of measurement was less than 10 minutes, this was only exceeded at a temperature of $35^{\circ} \mathrm{C}$ for the youngest individuals. Oxygen consumption was measured for $15 \mathrm{~min}$ ( $1-9$ day old voles); $30 \mathrm{~min}$, older ones.

F'or control purposes measurements of oxygen consumption were made at temperatures of $30^{\circ}$ and $35^{\circ} \mathrm{C}$, lasting 90 minutes each time. Litters of 4 or 5 voles were placed in the respiration chamber and their oxygen consumption recorded in successive periods of the experiment. The, values obtained in six successive 10jminute periods of measurement were compared, extrapolating each result to a full hour. Voles 4-6 days old at $\mathrm{T}_{\mathrm{A}} 30^{\circ} \mathrm{C}$ exhibit a certain decrease in oxygen consumption from the third 15-minute period of measurement (Table 6). The difference between the first and last measurement period is significant $(P<0.001)$, indicatir.g the distinct effect of this temperature on the metabolism of the youngest roles. At $35^{\circ} \mathrm{C}$, however, this relation was not observed. In voles $14-16$ days and 24-7 days old the length of measurements at $\mathrm{T}_{\mathrm{A} 30}$ and $35^{\circ} \mathrm{C}$ do not appear to exert ary influence on the results obtained for oxygen consumption (Table 6). The results of these control measurements show that 15 - and 30 minute runs give a good description of the metabolic rate of very young bank voles.

Although changes may be caused in the development of young, physiologicaly undeveloped, animals by keeping them outside the nest, particularly at low ter:peratures ( $\mathrm{H}$ a h $\mathrm{n}, 1956$; $\mathrm{H}$ a $\mathrm{r}$ is on, 1963), this obviously could not be avoidel. However, efforts were made to keep the young animals outside the nest for the shortest possible time and the different litters were used for the experiments not more than $3-4$ times during the first three weeks of life. It may be assumed that these precautions reduced any disturbance to their growth and development caused by handling. 
A total of 1076 measurements of oxygen consumption were made on 282 litters from 1 to 33 days old, born in spring (April-July) and 72 measurements on 34 litters from the autumn generation (October-November). The temperaturs at which the metabolic rate of the young voles was measured was from 15 to $35^{\circ} \mathrm{C}$, at $5^{\circ} \mathrm{C}$ intervals. Measurements were made on whole litters with natural differentiation of litter size. In addition oxygen consumption was measured separately for single individuals taken from the litter, consisting of 4 or 5 individuals, only for the time of the experiment.

Table 6

Oxygen consumption (ml/g hr $\pm \mathrm{SD}$ ) in six successive 15minute periods, by litters of 4 or 5 bank voles.

\begin{tabular}{|c|c|c|c|}
\hline \multirow{2}{*}{$\begin{array}{l}\text { Consecutive } \\
15 \text {-min. periods }\end{array}$} & \multicolumn{3}{|c|}{ Age in days } \\
\hline & \pm-6 & $14-16$ & 24-27 \\
\hline \multicolumn{4}{|c|}{ Ambient temperature $30^{\circ} \mathrm{C}$} \\
\hline I & $1.56 \pm 0.41$ & $2.38 \pm 0.42$ & $2.73 \pm 0.63$ \\
\hline II & $1.71 \pm 0.58$ & $2.27 \pm 0.63$ & $2.98 \pm 0.78$ \\
\hline III & $1.37 \pm 0.34$ & $2.74 \pm 0.79$ & $2.64 \pm 0.63$ \\
\hline IV & $1.12 \pm 0.27$ & $2.22 \pm 0.53$ & $2.37 \pm 0.44$ \\
\hline $\mathrm{v}$ & $1.17 \pm 0.27$ & $2.48 \pm 0.48$ & $3.14 \pm 1.01$ \\
\hline VI & $0.95 \pm 0.18$ & $2.63 \pm 0.67$ & $3.06 \pm 0.82$ \\
\hline Mean & $1.33 \pm 0.37$ & $2.45 \pm 0.56$ & $2.82 \pm 0.71$ \\
\hline Body wt., g & 3.2 & 7.1 & 12.2 \\
\hline $\mathrm{n}$ & 12 & 10 & 10 \\
\hline \multicolumn{4}{|c|}{ Ambient temperature $35^{\circ} \mathrm{C}$} \\
\hline I & $1.39 \pm 0.34$ & $2.78 \pm 0.42$ & $3.36 \pm 0.46$ \\
\hline II & $1.07 \pm 0.18$ & $3.08 \pm 0.58$ & $3.22 \pm 0.64$ \\
\hline III & $1.32 \pm 0.46$ & $3.17 \pm 0.47$ & $3.48 \pm 0.51$ \\
\hline IV & $1.86 \pm 0.62$ & $2.74 \pm 0.59$ & $3.17 \pm 0.59$ \\
\hline $\mathrm{v}$ & $1.46 \pm 0.49$ & $3.48 \pm 1.12$ & $3.12 \pm 0.76$ \\
\hline $\mathrm{VI}$ & $1.35 \pm 0.29$ & $3.39 \pm 0.68$ & $3.40 \pm 0.80$ \\
\hline Mean & $1.41 \pm 0.44$ & $3.11 \pm 0.78$ & $3.29 \pm 0.63$ \\
\hline Body wt., g & 3.1 & 6.2 & $11.9-0.00$ \\
\hline $\mathrm{n}$ & 8 & 10 & 9 \\
\hline
\end{tabular}

In the statistical analysis Students' $t$ test was used and the significance of differences was defined by the level $P<0.05$. If the difference was significant with a different $P$ this has been stated in the text.

\subsection{Results for the Spring Generation}

\subsubsection{Litter Size and Oxygen Consumption}

Although there is considerable variation in the oxygen consumption of the youngest bank voles, the effect of social thermoregulation is clearly perceptible from the first day of life. Smaller litters, particularly these consisting of only one or two young, have a higer metabolic rate than larger litters (Fig. 6). These differences are particularly clear in the youngest individuals from $1-3$ days old. Voles of this age, born and reared singly by their mothers, have an oxygen consumption rate twice 
as high at $T_{\mathrm{AZ0}}-\mathrm{T}_{\mathrm{A35}}$ as individuals from litters of 3 or more young. Litters of two individuals always have a lower metabolic rate, expressed
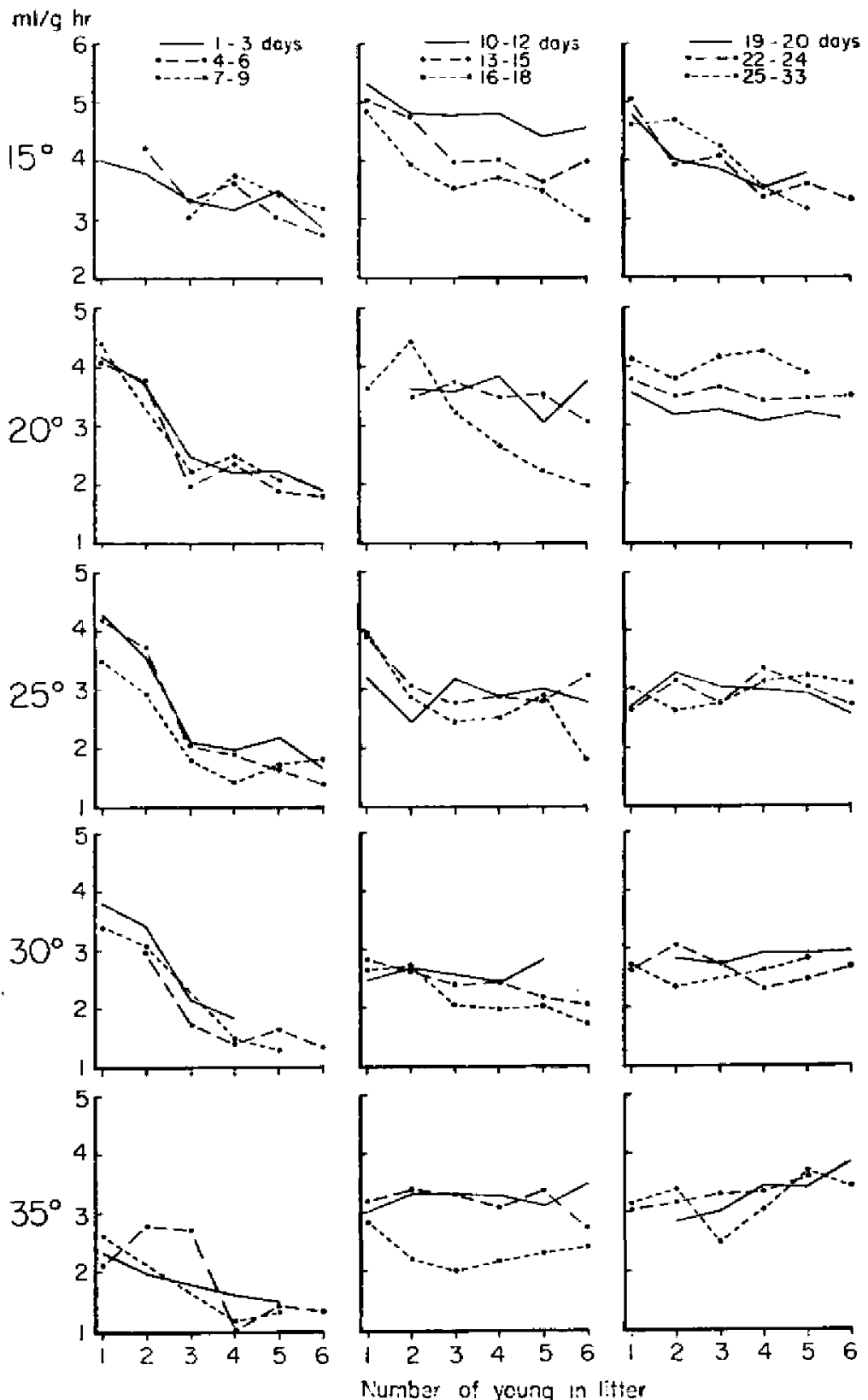

Fig. 6. Relation between age of bank voles, litter size and oxygen consumption rate at different temperatures. 
in units of body weight, than animals born singly, but higher than for larger litters. The differences between litters of 3 to 6 young are smaller and do not exceed $20 \%$ (Fig. 6). In older animals up to 12 days old, the kind of relation between litter size and metabolic rate remains the same and the differences are not significant.

The action of social thermoregulation is very clearly shown under cold conditions (Prychodko, 1958; Ponugaeva, 1960) and disappears at temperatures close to the neutral zone (G e bczyn ski, 1969). In the case of $C$. glareolus, however, during the first month of life this reaction differs from that in adults. From $\mathrm{T}_{\mathrm{A}^{20}}$ to $\mathrm{T}_{\mathrm{A}^{35}}$ individuals up to 9 days old from small litters always have a higher oxygen consumption than larger litters. At $\mathrm{T}_{\mathrm{A15}}$ this effect is even smaller, in bank voles from $7-9$ days old the difference was about $20 \%$ (Fig. 6). In older voles, from $10-12$ days old, the reduction in oxygen consumption rate with increase in litter size is very distinct at $\mathrm{T}_{\mathrm{A15}}$ and 20 and $25^{\circ} \mathrm{C}$. At $\mathrm{T}_{\mathrm{A} 39}$ the difference is smaller and at $\mathrm{T}_{\mathrm{A} 35}$ it disappears. Voles $13-15$ days old show a group effect only at $15^{\circ} \mathrm{C}$, while at higher temperatures the difference becomes insignificant. At the age of 16-18 days the group effect is only faintly marked in the young animals, irrespective of ambient temperature. In individuals over 19 days old reduction in metabolic rate in larger litters is perceptible only at $\mathrm{T}_{\mathrm{A15}}$. Social thermoregulation is not perceptible. It is only at $35^{\circ} \mathrm{C}$ that an increase in the number of very young voles causes a slight increase in oxygen consumption, when calculated per unit of body weight.

All these data show that in the first month of life of bank voles oxygen consumption depends on the number of young in a litter. Litter size does not, however, exert a constant and unvarying effect on metabolic rate, but this group effect depends both on age and on ambient temperature.

4.2.2. The Effect of Ambient Temperature on the Metabolic Rate of Single Individuals of Different Ages

Data on oxygen consumption were compared in three groups, according to age. The first group consisted of bank voles 1-9 days old, the second $10--18$ days old and the third $19-33$ days. The animals were divided into these groups in accordance with the stages of development of body temperature during these periods of life (cf. section 2). The youngest group is formed by individuals with a fairly constant but low $\left(33-34^{\circ} \mathrm{C}\right)$ body temperature. In the second group body temperature is characterized by continual increase on successive days of life, and the oldest group has a level of this index proper to adult individuals $\left(37-39^{\circ} \mathrm{C}\right)$.

The metabolic reaction of growing voles is also dependent on litter size, and consequently a separate analysis was made of data obtained on 

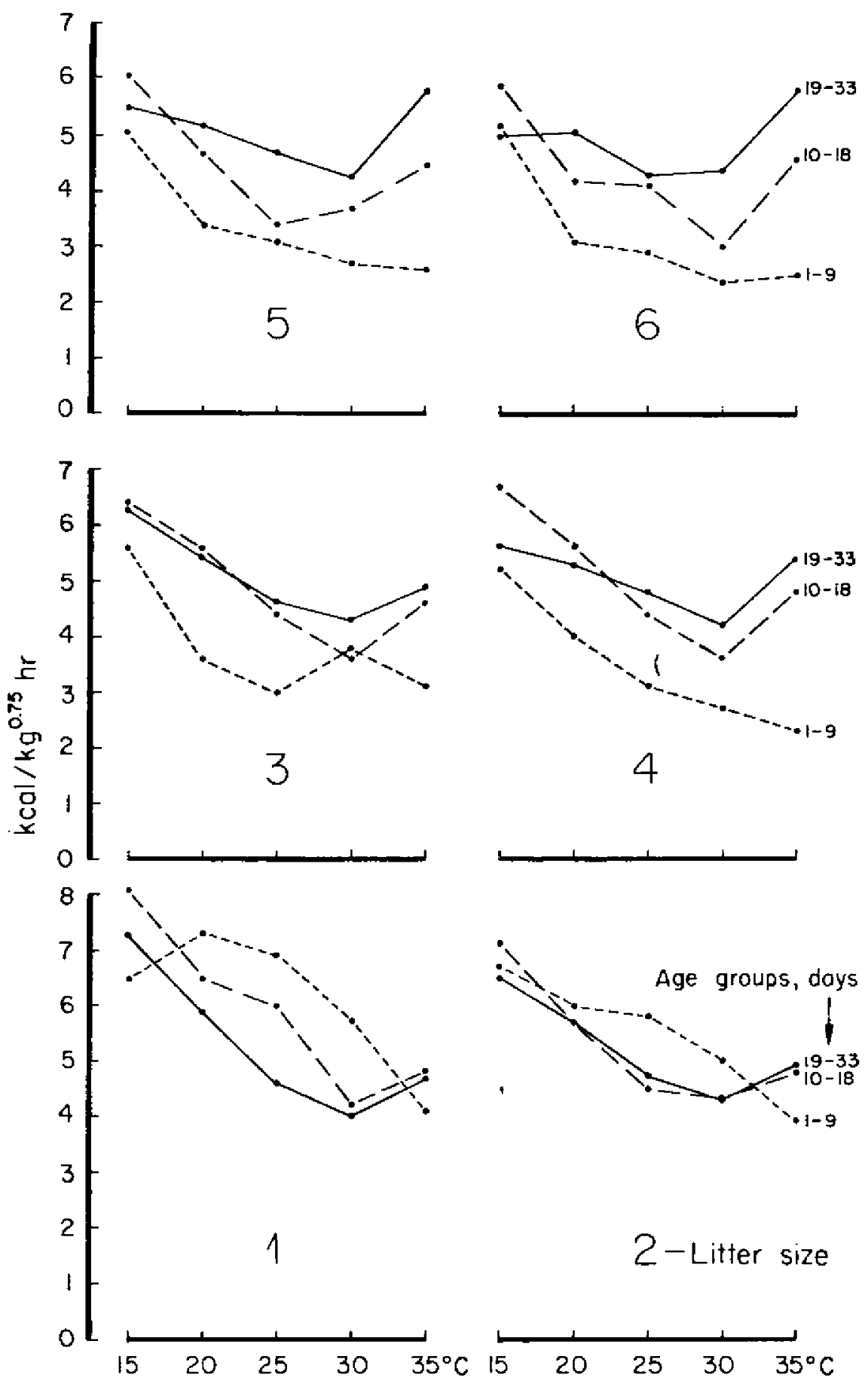

Fig. 7. Calorific requirements expressed in metabolic body size in litters of different size, depending on the age of the young voles. 
litters of 1 to 6 young, and also of single voles separated for the period of measurement.

$\mathrm{S}$ ing $\mathrm{l}$ e litters. In individuals $1-9$ days old oxygen consumption depends on ambient temperature only to a small extent. Within the temperature range of $T_{A 15}$ to $T_{A 25}$ this index remains unchanged. At $T_{A 30}$ oxygen consumption is lower, although not to a significant degree, but the difierence becomes significant $(P<0.01)$ at $\mathrm{T}_{\mathrm{A35}}$ (Table 7). Bank voles 10-.18 days old are distinguished by strong thermoregulatory reaction, since their oxygen consumption increases at lower ambient temperatures. At $T_{A 15}$ their metabolic rate is $91 \%$ higher than at $30^{\circ} \mathrm{C}$, and therefore a reduction of $1^{\circ}$ in ambient temperature brings about a $6 \%$ increase in oxygen consumption. Rodents from the oldest age group also exhibit a distinct thermoregulatory reaction, but it is slightly smaller, i.e, $5^{0} / 0^{\circ} 1^{\circ} \mathrm{C}$, showing that heat conservation mechanisms are better formed than at the age of $10-18$ days.

As differences in body weight between the various age groups are considerable, appearing as $1.0: 1.7: 2.9$, the results for oxygen consumption were calculated for metabolic body size, that is, unit of weight to the power of three quarters $\left(M W^{0.75}\right)$, after $\mathrm{K}$ l e i b e $\mathrm{r}$ 's generalisation (1961). The results (Fig. 7) show that the youngest group of bank voles from single litters do not exhibit thermoregulatory reactions at $\mathrm{T}_{\mathrm{A}}$ from 15 to $25^{\circ} \mathrm{C}$, although at temperatures from 20 to $30^{\circ} \mathrm{C}$ their metabolic rate is higher than in voles from 10-33 days old. Bank voles over 9 days old are characterized by a good metabolic reaction to the effect of cold and also heat.

Separated individuals. Single individuals about 4,14 and 24 days old were removed from litters of 4 or 5 young only for the duration of the experiment. After oxygen consumption had been measured the animals were returned to their original cages. The results obtained show that oxygen consumption rate is different from that in voles from single litters and also different from that in the litters from which the separated animals were taken.

Individuals 4 days old had a significantly higher oxygen consumption rate than those from single litters, and exceeded the values found for whole litters by twice as much (Fig. 8). At $\mathrm{T}_{\mathrm{A} 20}$ oxygen consumption by separated animals dropped significantly $(P<0.01)$ in comparison with $\mathrm{T}_{\mathrm{A15}}$. despite the considerable variations in results (Table 8 ). The fact is remarkable that oxygen consumption in 4 day old voles did not change at higher temperatures. Separated voles at the age of 14 days differ significantly from large litters, but when single litters are compared with separated individuals no significant differences are found at $T_{A 15}$, but the difference is significant at higher temperatures. There are 
insignificant differences irrespective of temperature between the metabolic rate of voles in large and single litters and separated individuals, in their fourth week of life (Table 7 and Table 8).

Comparisons of oxygen consumption by individuals examined singly and in litters of different size show that not only is there a considerable difference in metabolic rate, but also that the separated voles at the age of 4 and 14 days do not exhibit chemical thermoregulation at $T_{A 20}-T_{A 33}$.

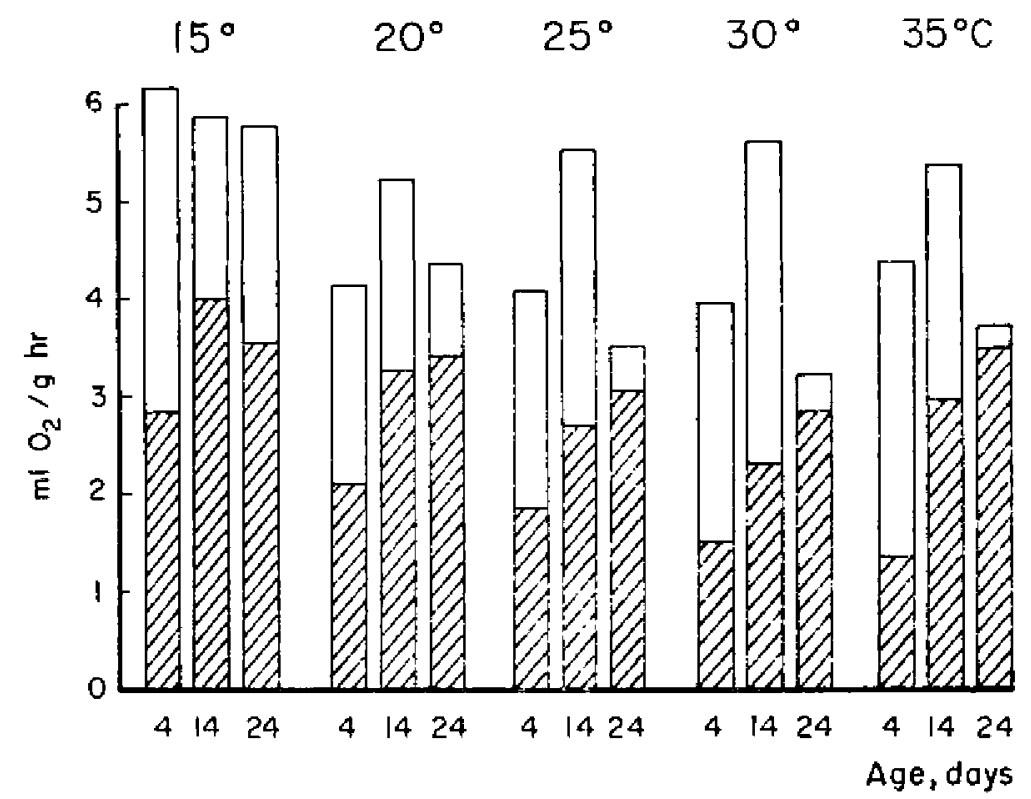

Fig. 8. Oxygen consumption rate in voles grouped in litters (shaded part of diagram) in comparison with the oxygen consumption rate of individuals removed from litters for the time taken by measurements (whole height of column).

As individuals measured singly had been removed from litters of 4 or 5 young, the results obtained were compared with the mean values for litters of 4 o: 5 young.

Only the temperature of $15^{\circ} \mathrm{C}$ causes a significant increase in metabolic rate. Young voles kept together with the other members of the litter during measurements exhibit a strong reaction to the effect of physiological heat and cold. Single litters exhibit intermediate reactions; the youngest group of 4-day old separated voles do not possess chemical regulation, but $10-18$ days old single litters differ from 14 day old separated voles. All these differences show that the capacity for in. creasing heat production under the influence of the thermal effect of 
their habitat also depends on behavioural stimuli created either by living in a litter or outside it.

Table 7

Changes with age in oxygen consumption expressed in $\mathrm{ml} / \mathrm{g} \mathrm{hr} \pm \mathrm{SD}$, by bank roles in litters of different size at different ambient temperatures.

\begin{tabular}{|c|c|c|c|c|c|c|c|c|c|}
\hline \multirow{2}{*}{$\begin{array}{l}\text { Litter } \\
\text { size }\end{array}$} & \multicolumn{3}{|c|}{$1-9$ days } & \multicolumn{3}{|c|}{$10-18$ days } & \multicolumn{3}{|c|}{ 19-33 days } \\
\hline & $\begin{array}{c}\mathrm{ml} / \mathrm{g} \mathrm{hr} \\
\pm \mathrm{SD}\end{array}$ & $\begin{array}{l}\text { Body } \\
w t ., g\end{array}$ & $\mathrm{n}$ & $\begin{array}{c}\mathrm{ml} / \mathrm{g} \mathrm{hr} \\
+\mathrm{SD}\end{array}$ & $\begin{array}{l}\text { Body } \\
\text { wt.. g }\end{array}$ & $\mathbf{n}$ & $\begin{array}{c}\mathrm{ml} / \mathrm{g} h \mathrm{hr} \\
\pm \mathrm{SD}\end{array}$ & $\begin{array}{r}\text { Body } \\
\text { wt., g }\end{array}$ & $n$ \\
\hline \multicolumn{10}{|c|}{ Ambient temperature $15^{\circ} \mathrm{C}$} \\
\hline $\begin{array}{l}1 \\
2 \\
3 \\
4 \\
5 \\
6\end{array}$ & $\begin{array}{l}3.99 \\
3.95 \pm 0.33 \\
3.29 \pm 0.31 \\
2.83 \pm 0.42 \\
2.91 \pm 0.47 \\
2.92 \pm 0.26\end{array}$ & $\begin{array}{l}3.8 \\
3.4 \\
3.4 \\
2.9 \\
3.1 \\
2.7\end{array}$ & $\begin{array}{r}3 \\
8 \\
28 \\
19 \\
15 \\
9 \\
\end{array}$ & $\begin{array}{l}5.08 \pm 0.38 \\
4.46 \pm 0.79 \\
3.99 \pm 0.76 \\
4.20 \pm 0.84 \\
3.80 \pm 0.60 \\
3.74 \pm 0.69\end{array}$ & $\begin{array}{l}6.4 \\
6.0 \\
6.3 \\
6.4 \\
5.8 \\
5.9 \\
\end{array}$ & $\begin{array}{r}7 \\
11 \\
27 \\
24 \\
27 \\
6\end{array}$ & $\begin{array}{l}4.80 \pm 0.59 \\
4.12 \pm 0.45 \\
4.08 \pm 0.41 \\
3.50 \pm 0.22 \\
3.59 \pm 0.49 \\
3.31\end{array}$ & $\begin{array}{r}9.5 \\
10.6 \\
9.3 \\
10.7 \\
10.0 \\
9.2 \\
\end{array}$ & $\begin{array}{r}30 \\
19 \\
25 \\
24 \\
17 \\
2 \\
\end{array}$ \\
\hline \multicolumn{10}{|c|}{ Ambient temperature $20^{\circ} \mathrm{C}$} \\
\hline $\begin{array}{l}1 \\
2 \\
3 \\
4 \\
5 \\
0\end{array}$ & $\begin{array}{l}4.19 \pm 0.76 \\
3.74 \pm 0.49 \\
2.18 \pm 0.37 \\
2.24 \pm 0.36 \\
2.03 \pm 0.59 \\
1.84 \pm 0.91\end{array}$ & $\begin{array}{l}3.2 \\
4.4 \\
3.6 \\
3.3 \\
3.6 \\
3.6\end{array}$ & $\begin{array}{r}9 \\
9 \\
16 \\
19 \\
23 \\
9\end{array}$ & $\begin{array}{l}4.04 \\
3.83 \pm 0.44 \\
3.48 \pm 0.73 \\
3.49 \pm 0.61 \\
2.94 \pm 0.16 \\
2.64 \pm 0.78 \\
\end{array}$ & $\begin{array}{l}5.7 \\
7.7 \\
6.7 \\
6.4 \\
5.9 \\
6.0\end{array}$ & $\begin{array}{r}3 \\
13 \\
17 \\
21 \\
10 \\
10\end{array}$ & $\begin{array}{l}3.67 \pm 0.81 \\
3.36 \pm 0.48 \\
3.59 \pm 0.52 \\
3.45 \pm 0.33 \\
3.33 \pm 0.56 \\
3.16 \pm 0.27\end{array}$ & $\begin{array}{r}11.4 \\
12.0 \\
9.6 \\
9.6 \\
10.2 \\
11.2 \\
\end{array}$ & $\begin{array}{l}12 \\
14 \\
32 \\
38 \\
16 \\
10\end{array}$ \\
\hline \multicolumn{10}{|c|}{ Ambient temperature $25^{\circ} \mathrm{C}$} \\
\hline $\begin{array}{l}1 \\
2 \\
3 \\
4 \\
5 \\
6\end{array}$ & $\begin{array}{l}4.13 \pm 0.28 \\
3.55 \pm 0.62 \\
2.01 \pm 0.40 \\
1.84 \pm 0.62 \\
1.87 \pm 0.51 \\
1.62 \pm 0.42\end{array}$ & $\begin{array}{l}3.6 \\
3.7 \\
3.7 \\
3.5 \\
3.5 \\
3.2 \\
\end{array}$ & $\begin{array}{r}7 \\
7 \\
17 \\
17 \\
10 \\
11 \\
\end{array}$ & $\begin{array}{l}3.73 \pm 0.25 \\
2.83 \pm 0.74 \\
2.78 \pm 0.68 \\
2.77 \pm 0.40 \\
2.88 \pm 0.64 \\
2.54 \pm 0.53\end{array}$ & $\begin{array}{l}4.9 \\
5.5 \\
5.6 \\
5.5 \\
6.3 \\
6.1 \\
\end{array}$ & $\begin{array}{r}7 \\
8 \\
16 \\
17 \\
11 \\
11 \\
\end{array}$ & $\begin{array}{l}2.76 \pm 0.63 \\
3.04 \pm 0.56 \\
2.94 \pm 0.43 \\
3.09 \pm 0.62 \\
3.02 \pm 0.49 \\
2.83 \pm 0.29\end{array}$ & $\begin{array}{r}12.7 \\
10.1 \\
10.2 \\
10.0 \\
9.9 \\
9.3 \\
\end{array}$ & $\begin{array}{r}4 \\
11 \\
17 \\
21 \\
6 \\
7 \\
\end{array}$ \\
\hline \multicolumn{10}{|c|}{ Ambient tempertaure $30^{\circ} \mathrm{C}$} \\
\hline $\begin{array}{l}1 \\
2 \\
3 \\
4 \\
5 \\
6\end{array}$ & $\begin{array}{l}3.59 \\
3.15 \pm 0.51 \\
2.04 \pm 0.38 \\
1.51 \pm 0.43 \\
1.49 \div 0.66 \\
1.32\end{array}$ & $\begin{array}{l}4.6 \\
4.0 \\
4.8 \\
3.1 \\
2.9 \\
2.9 \\
\end{array}$ & $\begin{array}{l}2 \\
6 \\
4 \\
9 \\
5 \\
1 \\
\end{array}$ & $\begin{array}{l}2.65 \pm 0.44 \\
2.67 \pm 0.82 \\
2.23 \pm 0.61 \\
2.27 \pm 0.49 \\
2.31 \pm 0.63 \\
1.90 \pm 0.73 \\
\end{array}$ & $\begin{array}{l}7.0 \\
6.5 \\
5.8 \\
6.2 \\
\mathbf{5 . 9} \\
\mathbf{5 . 4} \\
\end{array}$ & $\begin{array}{r}5 \\
8 \\
8 \\
6 \\
10 \\
4 \\
\end{array}$ & $\begin{array}{l}2.69 \pm 0.88 \\
2.73 \pm 0.62 \\
2.73 \pm 0.56 \\
2.90 \pm 0.62 \\
2.80 \pm 0.30 \\
2.81\end{array}$ & $\begin{array}{r}8.7 \\
10.6 \\
10.2 \\
10.5 \\
10.1 \\
10.0\end{array}$ & $\begin{array}{r}4 \\
15 \\
8 \\
14 \\
14 \\
2 \\
\end{array}$ \\
\hline \multicolumn{10}{|c|}{ Ambient temperature $35^{\circ} \mathrm{C}$} \\
\hline $\begin{array}{l}1 \\
2 \\
3 \\
4 \\
5 \\
6\end{array}$ & $\begin{array}{l}2.38 \pm 0.98 \\
2.37 \pm 0.66 \\
1.72 \\
1.30 \pm 0.42 \\
1.42 \pm 0.31 \\
1.33\end{array}$ & $\begin{array}{l}3.3 \\
3.8 \\
2.7 \\
3.1 \\
3.0 \\
2.5\end{array}$ & $\begin{array}{c}7 \\
4 \\
1 \\
7 \\
11 \\
2\end{array}$ & $\begin{array}{c}3.02 \pm 0.76 \\
2.98 \pm 0.45 \\
2.87 \pm 0.56 \\
3.02 \pm 0.41 \\
2.81 \pm 0.58 \\
2.90 \pm 0.30\end{array}$ & $\begin{array}{c}6.0 \\
6.6 \\
5.9 \\
6.3 \\
6.0 \\
6.3\end{array}$ & $\begin{array}{r}8 \\
9 \\
6 \\
19 \\
9 \\
5\end{array}$ & $\begin{array}{c}3.09 \pm 0.36 \\
3.04 \pm 0.61 \\
3.00 \pm 0.25 \\
3.31 \pm 0.52 \\
3.52 \pm 0.68 \\
3.64 \pm 0.45\end{array}$ & $\begin{array}{c}10.1 \\
11.2 \\
12.0 \\
11.5 \\
12.3 \\
10.8\end{array}$ & $\begin{array}{r}2 \\
11 \\
28 \\
21 \\
9 \\
4\end{array}$ \\
\hline
\end{tabular}

4,2,3. Effect of Ambient Temperature and the Size of the Litter (2-6 young) on the Metabolic Rate at Different Ages

Litters of $t w o$. Voles $1-9$ days old reduce their metabolic rate at $\mathrm{T}_{\mathrm{A} 15}-\mathrm{T}_{\mathrm{A} 30}$, but this difference is not significant. It is not until $\mathrm{T}_{A 35}$ that it is lower $(P<0.01)$ than at $30^{\circ} \mathrm{C}$. Unlike the young voles in 
single litters, animals over 9 days old have only a very slightly Iower respiration rate than that of voles below this age (Table 7). Oxygen consumption calculated for $M W^{0.75}$ shows that at $T_{A 15}$ and $20^{\circ}$ metabolic rate is similar regardless of age. At $\mathrm{T}_{\mathrm{A} 25}$ and $30^{\circ}$ it is higher in individuals $1-9$ days old and at $35^{\circ} \mathrm{C}$ is markedly lower than in the two older groups.

Litters of $t \mathrm{hr}$ ee. The development of a metabolic reaction to the effect of ambient temperatures in these voles differs from that in litters of two. Young voles from 1-9 days old from these and larger litters have a distinctly lower metabolic rate than older individuals. This

Table 8

Oxygen consumption by separated bank voles of different age.

\begin{tabular}{|c|c|c|c|c|}
\hline \multirow{2}{*}{$\begin{array}{l}\text { Ambient } \\
\text { tempera- } \\
\text { ture, }{ }^{\circ} \mathrm{C}\end{array}$} & & \multicolumn{3}{|c|}{ Age in days } \\
\hline & & $4-6$ & $14-16$ & $24-30$ \\
\hline 15 & $\begin{array}{l}\mathrm{ml} / \mathrm{g} \mathrm{hr} \pm \mathrm{SD} \\
\mathrm{kcal} / \mathrm{kg}^{0.75} \mathrm{hr} \\
\text { Body wt., g } \\
\mathrm{n}\end{array}$ & $\begin{array}{l}6.17 \pm 1.58 \\
10.96 \\
3.0 \\
20\end{array}$ & $\begin{array}{l}5.85 \pm 0.51 \\
9.58 \\
5.9 \\
20\end{array}$ & $\begin{array}{l}5.78 \pm 0.71 \\
9.04 \\
10.3 \\
19\end{array}$ \\
\hline 20 & $\begin{array}{l}\mathrm{mL} / \mathrm{g} \mathrm{hr}^{\prime} \pm \overline{\mathrm{SD}} \\
\mathrm{kcal} / \mathrm{kg}^{0.75} \mathrm{hr} \\
\text { Body wt., g } \\
\mathrm{n}\end{array}$ & $\begin{array}{l}4.14 \pm 0.61 \\
6.87 \\
3.5 \\
18\end{array}$ & $\begin{array}{l}5.21 \pm 0.74 \\
8.58 \\
7.1 \\
20\end{array}$ & $\begin{array}{l}4.35 \pm 0.86 \\
7.32 \\
12.8 \\
20\end{array}$ \\
\hline 25 & $\begin{array}{l}\mathrm{ml} / \mathrm{g} \mathrm{hr} \pm \mathrm{SD} \\
\mathrm{kcal} / \mathrm{kg}, 75 \mathrm{hr} \\
\mathrm{Body} \text { wt., g } \\
\mathrm{n}\end{array}$ & $\begin{array}{l}4.08 \pm 1.12 \\
6.79 \\
3.6 \\
12 \\
\end{array}$ & $\begin{array}{l}5.51 \pm 0.73 \\
8.85 \\
6.6 \\
24\end{array}$ & $\begin{array}{l}3 . \overline{51 \pm 0.70} \\
5.78 \\
13.1 \\
24 \\
\end{array}$ \\
\hline 30 & $\begin{array}{l}\mathrm{ml} / \mathrm{g} \mathrm{hr} \pm \mathrm{SH} \\
\mathrm{kcal} / \mathrm{kg} 0.75 \mathrm{~h} \\
\text { Body wt. g } \\
\mathrm{n}\end{array}$ & $\begin{array}{l}3.96 \pm 0.84 \\
6.74 \\
3.3 \\
31\end{array}$ & $\begin{array}{l}5.61 \pm 0.34 \\
8.57 \\
6.2 \\
40\end{array}$ & $\begin{array}{l}3.20 \pm 0.62 \\
5.38 \\
13.3 \\
14\end{array}$ \\
\hline 35 & $\begin{array}{l}\mathrm{ml} / \mathrm{g} \mathrm{hr} \pm \mathrm{SD} \\
\mathrm{kcal} / \mathrm{kg}^{0.75} \mathrm{hr} \\
\mathrm{Body} \text { wt.g } \\
\mathrm{n}\end{array}$ & $\begin{array}{l}4.28 \pm 0.95 \\
7.27 \\
3.4 \\
20\end{array}$ & $\begin{array}{l}5.36 \pm 0.90 \\
8.57 \\
6.4 \\
18\end{array}$ & $\begin{array}{l}3.73 \pm 0.86 \\
6.28 \\
12.9 \\
14\end{array}$ \\
\hline
\end{tabular}

difference also depends on ambient temperature, but is primarily due to age differences. At $\mathrm{T}_{\mathrm{A15}} 3$ voles in one litter consume significantly $(F<0.001)$ more oxygen than at $T_{A 20}$ (Table 7), but at higher temperatures these differences are not so great. A similar conclusion is reached when comparing values calculated for $M W^{0.75}$ (Fig. 7). In voles $10-33$ days old the dependence of metabolic rate on ambient temperature is already distinct (Table 6).

Litters of four. During the first 9 days of life voles have significantly higher oxygen consumption $(P<0.01)$ at $\mathrm{T}_{\mathrm{A} 20}$ than at $\mathrm{T}_{\mathrm{A} 25}$, and the difference between $T_{A 15}$ and $T_{A 20}$ is also significant. Temperatures over $25^{\circ}$, 
however, do not cause distinct differences in the metabolic rate of the youngest animals. Voles $10-18$ days old are distinguished by a significant dependence of oxygen consumption on ambient temperature $\left(T_{\mathrm{A} 1 \mathrm{~s}}-\mathrm{T}_{\mathrm{A} 30}\right)$, but $\mathrm{T}_{\mathrm{A} 95}$ causes a renewed significant increase in metabolic rate. Individuals at the age of $19-33$ days also reduce their metabclic rate with increase in temperature from $T_{A 25}$ to $T_{A 30}$ (Table 6).

Litters of $\mathrm{five}$ and $\mathrm{six}$. Reduction of $\mathrm{T}_{\mathrm{A}}$ from $20^{\circ} \mathrm{C}$ to $15^{\circ} \mathrm{C}$ causes a significant increase in oxygen consumption (Table 7 ), but an increase of $\mathrm{T}_{\mathrm{A}}$ to $35^{\circ} \mathrm{C}$ brings about only a negligible change in metabolic

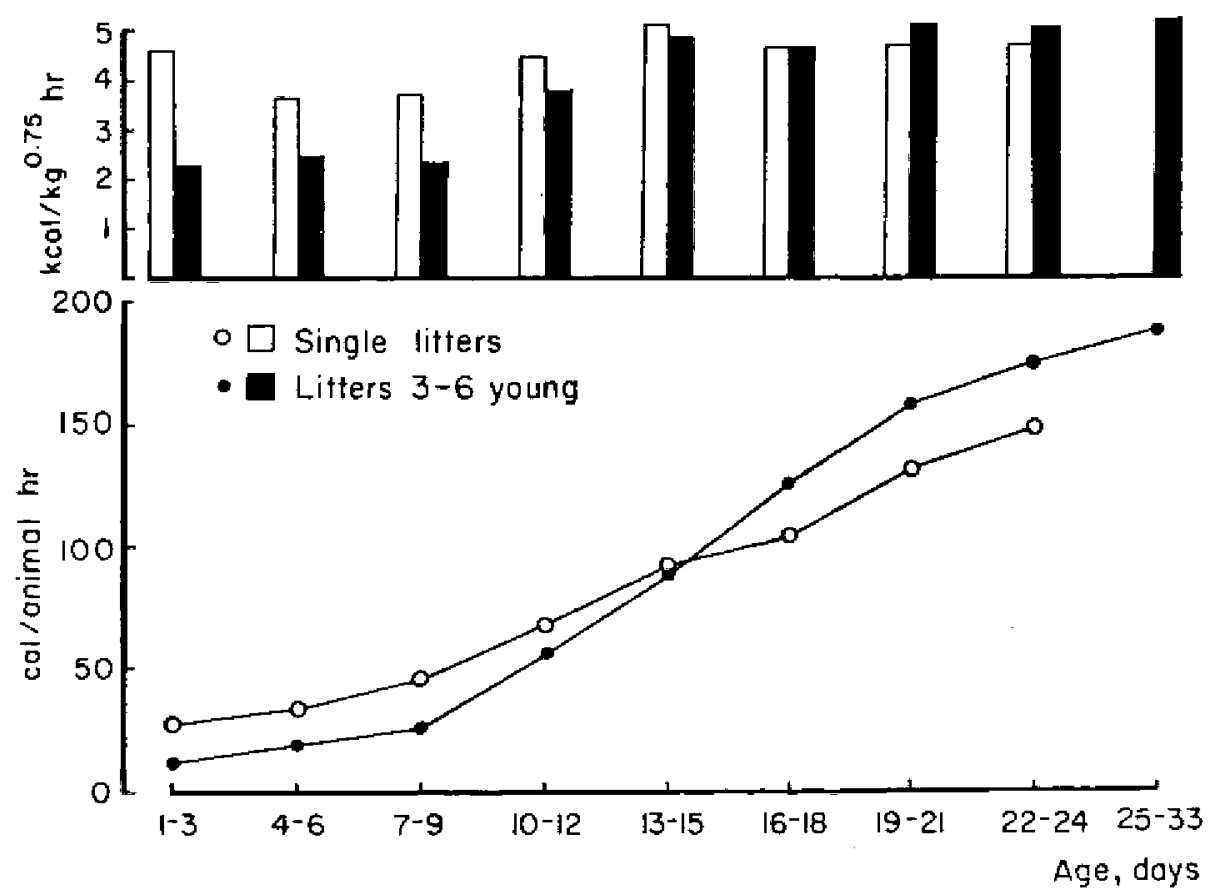

Fig. 9. Metabolic rate in voles at $T_{13 ;}$ in consecutive periods of the first month of life, the single litters were compared with the litters containing 3-6 young. Aterage body weight is given in Table 7 .

rate. Voles $10-18$ days old show only a slight increase in oxygen consumption above $\mathrm{T}_{A 25}$. In the oldest group the effect of temperature on metabolic rate is small, and this is confirmed when expressed as $M W^{0.75}$ (Fig. 7).

At a temperature close to the neutral zone the metabolic rate of litters containing from 3 to 6 young scarcely differs but is very different from the values found for single litters. In order to trace more exactly the age changes in the metabolism of voles growing in large and single 
litters, they have been presented over successive 3-day periods. At $\mathrm{T}_{\mathrm{A} J \mathrm{~J}}$ $M W^{0.75}$ is markedly higher during the first 12 days of life in single litters than in large ones (Fig. 9). These values are almost identical in older individuals. Similarly, when calculated for one individual, energy consumption in litters of 3 to 6 voles is lower during the earliest part of their life, but becomes higher in voles over two weeks old (Fig. 9). This is caused by the greater body weight of the voles growing in larger litters over this period (Table 7 ).

\subsection{Results for the Autumn Generation}

\subsubsection{Litter Size and Oxygen Consumption}

The number of animals born in autumn was too small to divide the values obtained according to the number of young in a litter, especially as the most frequent litter size was 3 or 4 . Only in one case that it proved possible to establish that litter size affects oxygen consumption that is at $T_{A 15}$ single individuals from $19-27$ days old are characterized by a higher metabolic rate than that for litters containing an average number of 3.6 young (Table 9). This difference is statistically highiy significant $(P<0.001)$.

4.3.2. The Effect of Age and Temperature on Metabolic Rate

The very small number of litters obtained for this generation did not allow the separation of the stages of development of body temperature and resistance to cooling during the postnataI period. Therefore the same division into age groups has been used as in the case of voles born in spring.

Oxygen consumption in bank voles of the autumn generation is highest at $T_{A 15}$, but is simultaneously dependent on age. Voles at the age of $1-9$ days have a significantly $(P<0.01)$ lower metabolic rate than those $10-18$ days old, while this group also has a significantly $(P<0.02)$ higher oxygen consumption rate than individuals $19-27$ days old (Table 9). A rise in ambient temperature leads to a reduction in metabolic rate, this being particularly marked in the youngest voles, when at $T_{A 30}$ oxygen consumption is $81 \%$ lower than that recorded at $\mathrm{T}_{\mathrm{A15}}$. Similarly the calculated difference for $10-18$ day old voles is $73^{\circ} / 4$, but only $20^{0} / \prime \prime$ for the oldest individuals.

Despite the differences in the metabolic reaction of the various age groups to the effect of ambient temperature, the amount of oxygen consumed at $\mathrm{T}_{\mathrm{A} 30}$ is also determined by the voles' age. The youngest group also has a significantly lower oxygen consumption rate at this temperature compared with voles from $10-28$ days old. On the other 
Table 9

Oxygen consumption by bank vole litters born in the autumn gencration.

\begin{tabular}{|c|c|c|c|c|c|c|c|c|c|c|c|c|}
\hline \multirow{2}{*}{$\begin{array}{l}\text { Ambient } \\
\text { tempera- } \\
\text { ture }{ }^{\circ} \mathrm{C}\end{array}$} & \multicolumn{4}{|c|}{$1-9$ days } & \multicolumn{4}{|c|}{$10-18$ days } & \multicolumn{4}{|c|}{$19-33$ days } \\
\hline & $\mathrm{ml}_{ \pm \mathrm{SD}}^{\mathrm{g} h \mathrm{t}}$ & $\begin{array}{l}\text { Body } \\
\text { wt., g }\end{array}$ & $\mathrm{n}$ & $\begin{array}{l}\text { Litter } \\
\text { size }\end{array}$ & $\begin{array}{l}\mathrm{mIg} h r \\
\pm \mathrm{SD}\end{array}$ & $\begin{array}{l}\text { Body } \\
\text { wt., g }\end{array}$ & $\mathrm{n}$ & $\begin{array}{c}\text { Litter } \\
\text { size }\end{array}$ & $\begin{array}{c}\mathrm{mlght} \\
\pm \mathrm{SD}\end{array}$ & $\begin{array}{l}\text { Body } \\
\text { wt., g }\end{array}$ & $\mathbf{n}$ & $\begin{array}{c}\text { Litter } \\
\text { size }\end{array}$ \\
\hline 15 & $2.89 \pm 0.27$ & 3.2 & 15 & 3.3 & $3.74 \pm 0.51$ & 5.6 & 12 & 3.2 & $3.33 \pm 0.29$ & 9.5 & 16 & 3.6 \\
\hline 15 & - & - & - & - & - & - & - & - & $4.22 \pm 0.61$ & 10.4 & 8 & 1 \\
\hline 20 & - & - & 二 & 二 & $2.86^{\circ}$ & 6.2 & 2 & 2.5 & 2.59 & 10.4 & 3 & 3.7 \\
\hline 25 & $1.88 \pm 0.21$ & 3.1 & 12 & 3.4 & 2,42 & 6.3 & 2 & 2.5 & 2.87 & 6.1 & 1 & $\begin{array}{l}3.1 \\
3.0\end{array}$ \\
\hline 30 & $1.60 \pm 0.36$ & 3.0 & 10 & 3.3 & $2.16 \pm 0.60$ & 5.5 & 12 & 3.2 & $2.79 \pm 0.42$ & 8.4 & 5 & 3.4 \\
\hline 35 & 1.21 & 2.9 & 2 & 3.5 & 2.77 & 6.0 & 1 & $\begin{array}{l}3.2 \\
3.0\end{array}$ & 二 & - & - & - \\
\hline
\end{tabular}


hand the difference dividing this group from the oldest animals is on the borderline of significance (Table 9). At $T_{A 35}$ metabolic rate is even more closely dependent on age, but the small amount of data obtained did not allow the statistical significance to be marked.

\section{4,4. Differences between Generations}

Data on oxygen consumption for the spring generation were interpolated to the size of litters characteristic of the autumn generation, and were expressed per metabolic body size so that the two generations could be compared. The bank voles born in spring have, in almost all

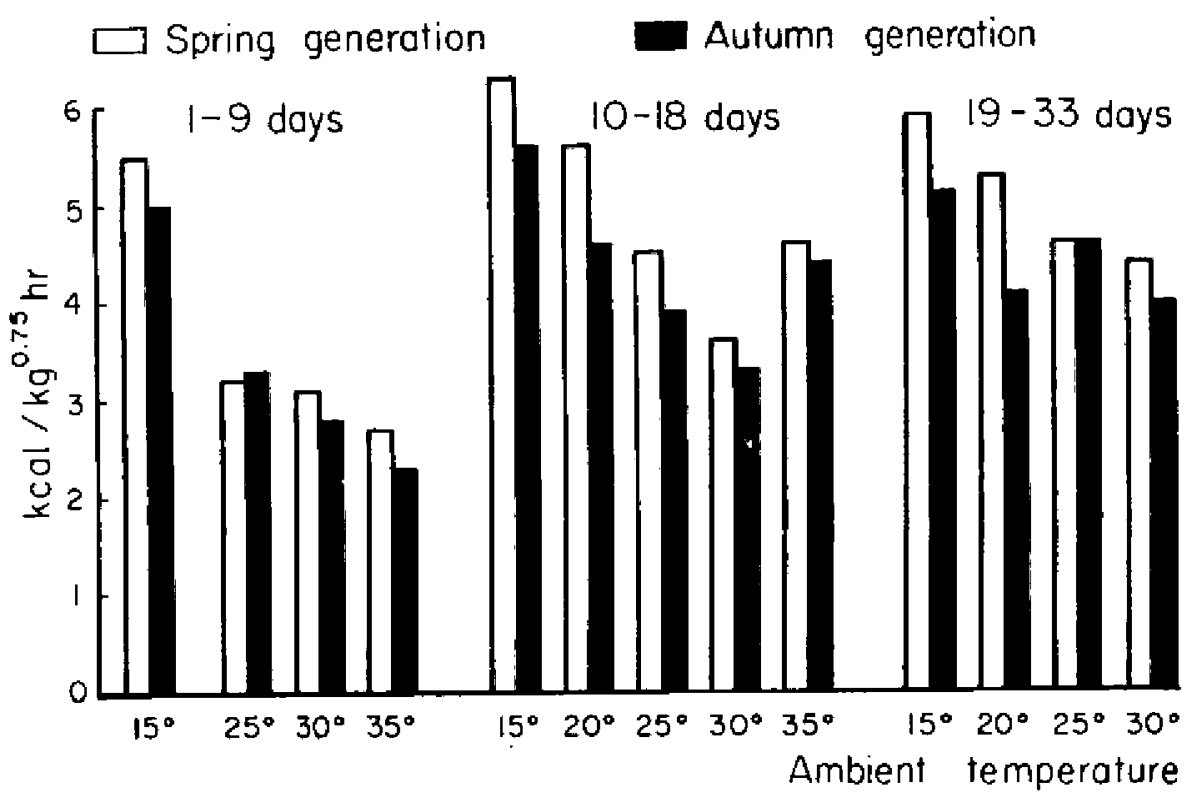

Fig. 10. Comparison of metabolic rate at different temperatures expressed in calorific requirements per metabolic body size $\left(\mathrm{kg}^{0.75}\right)$ for roles of different age and coming from the spring and autumn generations.

cases, a higher metabolic rate, than those born in autumn (Fig. 10). The size of differences does not depend so much on age, but on the effect of ambient temperature. It is most distinct at $\mathrm{T}_{\mathrm{A} 15}$ and $20^{\circ} \mathrm{C}$. but is very slight at higher temperatures. All these differences are not, however, significant, except for single litters, which differ significantly at $15^{\circ} \mathrm{C}$. The picture of the metabolic properties observed in growing voles thus indicates that there is some retardation of the development 
rate in animals born in autumn. However, these differences are not sufficiently great to be able to state that the development pattern is different in the two generations.

\subsection{Discussion}

In the bank vole heat production mechanisms are not fully developed during the immediate postnatal period. This development depends on age (metabolic rate is higher in older animals) and on litter size. Young voles from small litters ( $1-2$ individuals) have a different metabolic rate at given temperatures than individuals from larger litters $(3-6)$. However, the oxygen consumption rate of individuals separated for the duration of measurements is twice as high as that for whole litters. In addition, it only partly agrees with results for young voles born and reared singly. It would therefore appear that the only way to measure the characters of young bank voles living with their siblings is to treat them together as a group. This conviction, which is obvious to ethologists concerned with relations between the mother and her offspring, is slowly finding acceptance among physiologists (M ount, 1960; Cosnier, Duveau \& Chanel, 1965).

The rate at which metabolic reaction is formed in the bank vole is rapid, as suggested by the results obtained by $B$ ashenina \& $B$ orovskaja (1963) in their observations of the development of 6 litters. A significant increase in metabolic rate occurs on the final days of the second week of life. Nevertheless, despite the low metabolic rate on the first few days after birth, the effect of cold for 15 minutes causes considerable increase in oxygen consumption. Although measurements made for $11 / 2$ hours at $\mathrm{T}_{\mathrm{A}} 30^{\circ}$ revealed a decrease of $40 \%$ in metabolic rate in voles 4-6 days old, the first two 15-minute periods of the measurement show that chemical thermoregulation exists, and thus even on the first few days after birth oxygen consumption by voles increases under cold conditions, as it does in the case of laboratory mice ( $\mathrm{C}$ a s $\mathrm{s}$ i $\mathrm{n}$, 1963) and rat ( $\mathrm{T}$ a y lor, 1960a). This contradicts the opinion that small rodents are completely incapable of increasing oxygen consumption when ambient temperature drops.

The reduction in oxygen consumption rate in voles $4-6$ days old when measurements are made for a considerable time can be explained to some extent by the fact that the chemical thermoregulation of replete individuals is markedly higher than in hungry ones (B a rić, 1953; T a y lor, 1960b). This relation was not, however, observed in very young laboratory mice (Fitzgerald, 1953). The corbohydrate reserves of a newborn rat are very low (Mour e k, 1958), so that hungry 
individuals would be expected to have a reduced oxygen consumption in cold conditions. It would seem that it is not the explanation of the differences in metabolic rate and reaction to cold in bank voles depending on litter size. Small litters are undoubtedly better fed and that is why their metabolism and reaction to cold differs from those of less well fed individuals from larger litters. This does not mean that young voles from small litters have more favourable conditions for development than individuals from large litters. It has been found under field conditions that mortality among litters consisting of 4 to 7 young is lower than in smaller litters (Ryszkowski \& Truszkowski, 1970). It may therefore be concluded that the low metabolic rate characteristic of large litters is a character preferred by natural selection, despite the fact that the amount of food available for each of its members is relatively smaller than in litters with fewer individuals. Reduction in energy losses is thus more important to the voles' survival than increase in its potential sources.

In voles $10-18$ days old oxygen consumption is sometimes higher than in older animals. This is connected with the fact that their heat production mechanisms are already well developed, but not their fur and vasumotor reactions. Bank voles can therefore produce a considerable amount of heat which is lost more quickly than in older individuals.

The season of birth exerts only an influence on the rate at which metabolic reaction is formed. Bank voles born in winter in captivity (cf. section 5), like rats born at an ambient temperature of $5^{\circ} \mathrm{C}(\mathrm{C} \mathrm{h}$ e vi llard, Portet \& $\mathrm{Cadot}, 1963)$, grow more slowly, and also have a higher tissue metabolism ( $\mathrm{G} \mathrm{ę} \mathrm{b} \mathrm{c} \mathrm{z} \mathrm{y} \mathrm{ński,} \mathrm{1975)} \mathrm{confirmating} \mathrm{that}$ they are physiologically (metabolically) younger.

The examination of the oxygen consumption of voles during the first month of life shows that a short period in a temperature even as low as $15^{\circ} \mathrm{C}$ causes a distinct increase. The degree of this reaction is clearly different in young voles from small and large litters, but the metabolic reaction of young voles up to about the 9 th day of life is not as constant as in older animals. Metabolic rate is also low in the youngest voles and does not increase quickly until the animals are older. Therefore the constant body temperature observed in the bank vole during the period of postnatal development (cf. section 2) is ensured not only by the mother's behaviour or presence of the nest and by the young voles huddling together in a litter. Such a litter can produce more heat when subjected to the effect of cooling than can an individual. Group thermoregulation consists of improving the relation between body surface and its weight (Gębczynski, 1969). Hence heat production by a litter is subject to smaller fluctuations than in single individuals in which 
hypothermy restricting metabolism may easily take place. It must, however, be remembered that the result of metabolism in a group also depends on social relations and reactions (P on uga e va, 1960; M y rcha \& Szwykowska, 1969; My r cha, 1975), and these phenomena are completely unknown in rodent litters. It is possible that these factors also may determine the greater capacity for survival of large litters.

\section{B. THE ENERGY COST OF NESTLING DEVELOPMENT}

\section{THE COST OF GROWTH IN NESTLINGS AT DIFFERENT TEMPERATURES}

The increase in the mother's calorific requirements during her gestation and lactation periods is due to the necessity for transmitting part of the assimilated energy to her offspring. In the bank vole, which produce 5 and rears 4 young, according to $\mathrm{Kaczmarski}$ estimate (1966) energy requirements increased by $24 \%$ during gestation and by $92 \%$ during lactation. This considerable metabolic burden may be increased even more, when litters are larger, but may be reduced when the number of offspring is small. Since nestling development rate in captive bank voles clearly depends on the season of birth, measurement were made of the food consumption of parents rearing litters in winter and in spring. This allowed the estimation of the relation between maintenance costs and growth of the litter rate of growth and development of the young. In addition a series of measurements were made in spring at low tenperatures in order to estimate the effect of ambient temperature on the above correlation.

\subsection{Material and Methods}

Measurements of food consumption were made on voles rearing young at a temperature of $20.3^{\circ} \mathrm{C}$ (winter I series), $19.7^{\circ} \mathrm{C}$ (spring II series) and $9.0^{\circ} \mathrm{C}$ (spring III series). For purposes of comparison about 10 pairs without offspring were kept under identical conditions for each series. All the animals used for the experiments were taken from among those kept in captivity in the laboratory, the conditions of which have been described by Buchalczyk (1970).

The voles were supplied with husked oats, carrot and water. Unconsumed food was weighed daily to determine the amount consumed, which was expressed as dry mass. Food consumption and changes in body weight were assessed for three successive days of each week. On the remaining day food and water were supplied without touching the young, in order to reduce the effect of handling on their growth. The voles were kept in plastic cages measuring $30 \times 20 \times 10 \mathrm{~cm}$, with wire mesh lids. The nest material consisted of cotton-wool, $30 \mathrm{~g}$ of which was supplied for room temperature conditions and $40 \mathrm{~g}$ for the lower temperature.

When calculating the energy budget of adult individuals, a correction was introduced for changes in body weight, adding $7 \mathrm{kcal} / \mathrm{g}$ for weight loss, and sub- 
tracting $9 \mathrm{kcal} / \mathrm{g}$ when weight increased, on the assumption that lipids are the main material utilized or deposited (D $\mathrm{r}$ o $z \mathbf{d} \dot{z}, 1968$ ). The coefficient of digestion and assimilation of voles fed on the same food varied very little, being $86.3 \%$ and $85.0 \%$, depending on ambient temperature (G ę bczyńs i \& Gęb czy ńs ka. 1971). As the difference in temperatures in this study was $16^{\circ} \mathrm{C}$, greater than in the present study, two different values were not introduced. It was assumed that $85 \%$ energy was assimilated in all calculations.

\subsection{Results}

The combined food requirements of a male and female not rearing offspring were established by means of 24-hour measurements at temperatures of $20^{\circ} \mathrm{C}$ and $9^{\circ} \mathrm{C}$ (Table 10 ). At the lower temperature these are over $20 \%$ greater than at room temperature. Both these values, expressed as assimilated energy, were used for calculating the energy requirements of litters, since the values appropriate to parents without offspring were subtracted from the requirement values measured for parents with offspring. Calculations of the litter's energy requirements

Table 10

Food consumption by pairs (male + female) not rearing offspring. $n$ indicates number of measurements of daily food requirements expressed in units of assimilated energy.

\begin{tabular}{cccccc}
\hline $\begin{array}{c}\text { Ambient } \\
\text { temperature } \\
{ }^{\circ} \mathrm{C}\end{array}$ & $\begin{array}{c}\text { Mean weight } \\
\text { of the pairs, } \mathrm{g}\end{array}$ & $\mathbf{n}$ & $\begin{array}{c}\text { kcal pair } \\
\text { per day }\end{array}$ & $\begin{array}{c}\text { kcal:g } \\
\text { per day } \pm \pm \mathrm{SD}\end{array}$ & $\begin{array}{c}\text { Differences in } \\
\text { consumption. }\end{array}$ \\
\hline 20.1 & 45.0 & 36 & 18.96 & $0.422 \pm 0.103$ & 100.0 \\
9.0 & 44.3 & 99 & 22.55 & $0.509 \pm 0.089$ & 120.6 \\
\hline
\end{tabular}

were limited to the first 10 days following birth, when the only source of food for the young is their mother's milk. Thus costs of food conversion to milk enter into the established value.

Owing to the use of litters varying in size from 1 to 5 young, it was possible to show that an increase in the size of the litter is accompanied by increased energy requirements for its support during the first two weeks of life. The coefficient of correlation between these is 0.49 in series I and is even lower in series II and III, being 0.31 and 0.29 , respectively. This shows that, with the number of measurements discussed, there are no significant relations between the number of young in a litter and daily energy expenditure by the parents. The differences in food consumption of voles rearing offspring cannot therefore be explained by the different number of young in a litter.

On the other hand by comparing the calculated expenditure on the litter's maintenance with the rate of growth of body weight for the 
Table il

Energy requirements of bank voles rearing offspring.

The measured value of food requirements was calculated only for the first 14 days of life of young voles while still constantly in the nest. Requirement value was converted to assimilated energy $(85 \%$ of gross energy). Consumption of a female and male not rearing offspring, determined in control experiments, made it possible to calculate the parents' requirements, the difference being treated as the cost of supporting offspring. The litters were weighed and these data form the basis for calculations of the relation between increase in body weight and energy cost of supporting offspring. Each measurement indicated a mean value for a 14-day experiment.

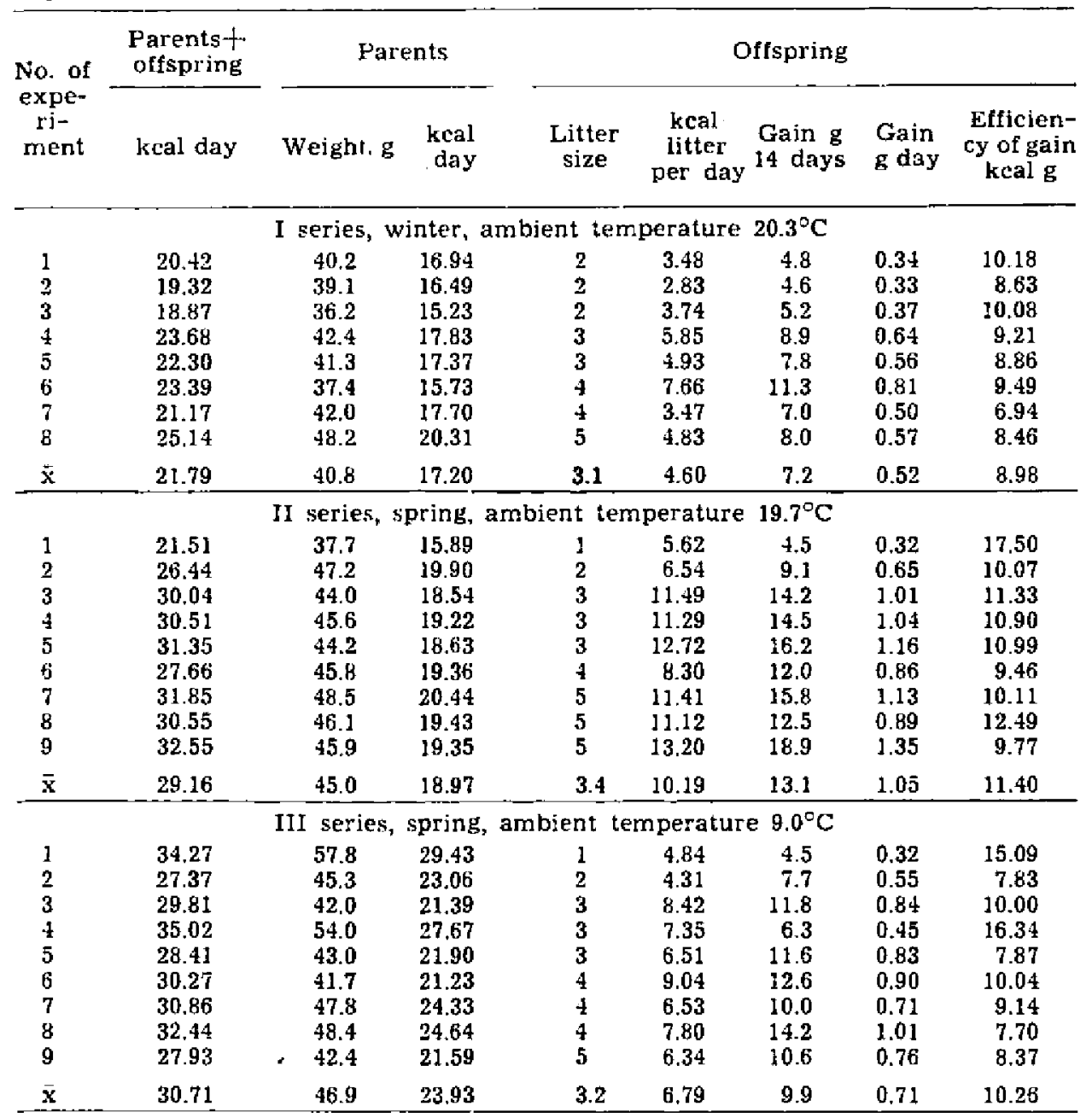

litter, very high correlation was obtained for these two characters. The equation of regression for these relations are:

series I, $20.3^{\circ} \mathrm{C}$, winter, $Y=0.514+0.084 x ; r=0.95 \quad P<0.001$

series II, $19.7^{\circ} \mathrm{C}$, spring, $\mathrm{Y}=0.934+0.106 x ; r=0.93 \quad P<0.001$

series III, $9.0^{\circ} \mathrm{C}$, spring, $Y=0.697+0.132 x ; \tau=0.86 \quad P<0.001$ 
Although the amount of energy used for increase of $1 \mathrm{~g}$ of body weight of the offspring is 7.8 assimilated kcal, to $17.5 \mathrm{kcal}$, it is only in thriee cases out of the 26 examined that the figure of 15 is exceeded These three litters consisted in one case of three young, and in two other vases were single litters (Table 11). In both single litters the increase in body weight per individual is high, while it is relatively low in the third litter. All the other litters come within limits of $10 \pm 2 \mathrm{kcal}$. No distinct relation between this index and season of birth, growth rate or ambient temperature can be found. Litters kept at a temperature of $9^{\circ} \mathrm{C}$ need the least energy for an increase in body weight of $1 \mathrm{~g}$, although the difference is not significant.

Various litters differ by as much as five times in the value of the weight increase due to growth during the first two weeks of their life. This is due in some measure to the litter size, since increase per individual in different litters differs by a factor of only 2.5 . In series I the voles were born in winter, having a growth rate of $0.5 \mathrm{~g} /$ day/litter. However, the voles born in spring (series II, April; series III, March) have respecively a distinctly higher growth rate of 0.9 and $0.7 \mathrm{~g} /$ day/litter. Differences between series II and III may be due to the effect of lower ambient temperature (Chevillard et al., 1963), and also to the fact that litters in series III are slightly smaller.

The expenditure of energy on rearing young also increases during the successive days of life of the offspring. For instance, the average food requirements of adults during the first week of life of their young is $28.7 \mathrm{kcal}$, but $32.4 \mathrm{kcal}$ in the second week. Reduction in such expenditure undoubtedly begins when the young sucklings begin to ext solid food in addition to milk, which is observed for the first time in young voles on the 15th day of life (Sviridenko, 1959; Mazak, 1962).

\section{5,3, Discussion}

The rate of growth of the laboratory rat and laboratory mouse depends on the number of animals in the litter. The explanation for this is that the mother is not able to feed larger litters well (see review by $\mathrm{H}$ a hn \& Koldovsky, 1966). A similar relation was also found between litter size and rate of growth in wild species of rodents (C a m e r o.a. 1973). In litters of $3-5$ bank voles the body weight is higher on the 20 th day of life than of individuals from litters of 6-9 individuals (Korabelnik ov, 1972). As, however, growth rate depends significantly on many other factors, the effect of the number of young $n$ litter varies in importance. Vetulani (1931) has in fact shown thit 
the growth of laboratory mice kept singly is poorer than that of mice kept together.

The studies presented on the costs of rearing offspring show that in groups of 5 voles the growth rate per individual is lower than in single litters. The cost of an increase of $1 \mathrm{~g}$ of body weight in larger litters is also markedly lower than in single litters. Two of the single litters examined have far higher growth costs, but their metabolic rate is also markedly higher than that of all the larger litters.

Despite the fact that the lower ambient temperature causes an increase in heat losses, this does not bring about a change in the cost of rearing young. The fact that this index is even slightly lower in voles reared at $9^{\circ} \mathrm{C}$, as in the case of laboratory mice (B a rnet $\&$ Little, 1965), than at $20^{\circ} \mathrm{C}$ must be explained as due both to better parental attentiveness and also to some reduction in the body temperature of the young voles (cf. section 2). This last factor was undoubtedly the cause of the reduction in the growth rate of individuals from group III as compared with group II.

Neither reduction in growth rate caused by lower ambient temperature nor the low growth rate in voles born in winter alters the fact that the cost of rearing young calculated per unit of increase in their mass would appear to be fairly constant. Thus the cost of rearing young may be assumed to be constant under natural conditions, and therefore the costs borne by the mother are directly related to the rate of increase in the body weight of young voles.

The question whether under natural conditions the growth of the bank vole during the first month of life depends on the season has remained unsolved up to the present time. It is, however, certain that further growth in voles born in spring is more rapid than in those born in autumn (Wasilewski, 1952; Ilyenko \& $\mathrm{Zubchaninova,}$ 1963; Bergstedt, 1965; K u bik, 1965). Experiments have shown that both poorer food conditions (Sviridenko, 1959) and lower temperature (this paper) may retard the growth of young voles, nevertheless it is considered that under natural conditions during the first $3-4$ weeks of the young bank vole's life it grows at a uniform rate, irrespective of the season (Bujalska \& Gliwicz, 1968; Zejda, 1971; Fedyk, 1974b; Sawicka-Kapusta, 1974). Bergstedt (1965) opposed this opinion. It must, however, be strongly emphasised that all opinions on nest growth are based on laboratory data, or on extrapolated values defined for bank voles caught in the second month of life. The difficulty of determining age in growing bank voles under field conditions is demonstrated by Bergsted t's statement (1965) that he considers that voles 10 days old made short excursions in the 
vicinity of the nest. Data on postnatal development (cf. Sviridenko, 1959; $\mathrm{M}$ a $\mathrm{z}$ a $\mathrm{k}$, 1962) however, show, that at this age bank voles are still blind.

There is thus still a lack of convincing information on the relation between the season in which the bank vole is born and the rapidity of its growth during the nest period. Under experimental conditions the reduction of total expenditure on rearing young is effected by slowing down their growth rate. Under natural conditions, however, reduction of the same expenditure may perhaps be achieved at the expense of litter size. Support for this interpretation is provided by the fact that litter size is about $40 \%$ smaller under the poorer autumn conditions than in spring ( $\mathrm{Zejda}, 1966$; Ryszkowski \& Truszkowski, 1970). It may therefore be concluded from this that the rate of nest growth is similar in all generations. Presumably an individual with excessively small body measurements would have smaller chances of successfully begining independent life.

\section{ENERGY ACCUMULATION IN GROWING BANK VOLES}

The maintenance costs of well-protected young voles remaining constantly in the nest are small, and it may therefore be assumed that their rapid growth is an energetically productive process which enables the bank vole to produce offspring at low cost. Indices defining this productivity are formed by the ratio of the amount of energy deposited in the organism to the amount of energy assimilated. Energy assimilated $(A)$ is expended on maintenance costs ( $R$ - respiration) and may also be deposited in the form of body components ( $P$ - production). Knowing the relevant values, it proved possible to calculate the coefficient of production efficiency $K=(P / A) \times 100$ for assimilated energy.

\subsection{Calculations}

The amount of energy accumulated in the form of tissues $(P)$ of the growing organism can in theory be exactly measured, since it is equal to the body mass multiplied by its calorific equivalent. In practice, however, the body growth rate is known only from observations made under laboratory or semi-natural conditions (cf. discussion in section 5). In addition this index is subject to considerable fluctuation. The majority of the data, however, show that during the first month of life the increase in a vole's body weight is about 9 to $13 \mathrm{~g}$ (for references see General Introduction). Although in the opinion of some authors (M a z a k, 1962; Pearson, 1962) growth rate during the first month of bank vole's life is not smooth, many other data (Bujalska \& Gliwicz, 
1968; Sawicka-Kapusta, 1974; Fedyk, 1974a; author's own data) show that it is in fact variable and not related to the age of the young. It depends, for instance, on litter size ( $R$ ö d I, 1973), since it is uniform in small litters, which is not the case with large ones.

The calorific value of body tissue in the bank vole alters markedly during the first four weeks of life. Although the energy value of fat and proteins remains constant and independent of age ( $\mathrm{F}$ e d y k, 1974a) the amount of water in individuals of the spring generation decrease from $85.3^{1 \%}$ on the first day after birth to $72.7^{0} / n$ on the thirtieth day after birth. Reduction in the relative water content in the body with simultaneous growth of the body results in the weight of protein increasing 14 times and fat by as much as fifty times, while water increases

Table 12

Variations in gross body composition and calorific value of the bank vole during the first month of postnatal life.

1 - data calculated after Sawi ka-Ka pusta, 1974, obtained for bank voles kept in an outdoor enclosure under semi-natural conditions; 2 - data calculated after Fed $y k$, 1974b, for young born in the spring generation.

\begin{tabular}{|c|c|c|c|c|c|c|c|c|c|}
\hline \multirow{2}{*}{$\frac{\text { Age, days }}{\text { Authority }}$} & & \multicolumn{2}{|c|}{1} & \multicolumn{2}{|c|}{10} & \multicolumn{2}{|c|}{20} & \multicolumn{2}{|c|}{30} \\
\hline & & 1 & 2 & 1 & 2 & 1 & 2 & 1 & 2 \\
\hline \multirow{3}{*}{$\begin{array}{l}\text { Body urt., } \text { g } \\
\text { Water }\end{array}$} & $g$ & 2.20 & 1.74 & 5.33 & 3.90 & 7.86 & 5.36 & - & 12.11 \\
\hline & $\%$ & 83.2 & 83.0 & 72.5 & 74.5 & 70.9 & 76,0 & - & 75.9 \\
\hline & $\mathrm{g}$ & 1.83 & 1.44 & 3.86 & 2.94 & 5.57 & 4.07 & - & 9.19 \\
\hline \multirow[t]{2}{*}{ Fat } & $\%$ & 5.0 & 2.7 & 11.8 & 8.3 & 11.7 & 8.8 & - & 5.2 \\
\hline & $\mathbf{g}$ & 0.11 & 0.05 & 0.63 & 0.33 & 0.92 & 0.47 & - & 0.66 \\
\hline \multirow{2}{*}{ Protein } & $\%$ & 10.0 & 11.4 & 13.5 & 13.9 & 14.6 & 11.9 & - & 16.3 \\
\hline & $\mathbf{g}$ & 0.22 & 0.20 & 0.72 & 0.55 & 1.15 & 0.64 & - & 1.97 \\
\hline \multirow[t]{2}{*}{ Ash } & $1 / 0$ & 1.8 & 2.1 & 2.2 & 2.2 & 2.8 & 3.3 & - & 2.6 \\
\hline & $\mathbf{g}$ & 0.04 & 0.04 & 0.12 & 0.09 & 0.22 & 0.18 & - & 0.31 \\
\hline kcal/animal & & 2.024 & 1.379 & 9.121 & 5.570 & 13.771 & 7.449 & & 15.126 \\
\hline
\end{tabular}

only six times, the mineral substance content of tissues also increasing (F e d y k, 1974b).

The energy value of the deposited tissue is equal to the sum total of the deposited protein and fat. Differences in the amount of these substances are evident as early as the first day of the vole's life (Table 12) and last over the whole period of growth. The data given, presenting a certain range of variation, allow the estimation of the proauctivity index in individuals growing either quickly or slowly.

Calculation of the respiration level $(R)$ was based on the results of measurements of oxygen consumption by litters having an average of 4 young (see Table 7). It was assumed that the mother spends 18 hours out of the 24 in the nest with her offspring, and that during this time the nest temperature was approx. $34-35^{\circ} \mathrm{C}$, as in the case of albino 
mice (L a gerspet $z, 1966$ ). Nest temperature is from $3-5^{\circ} \mathrm{C}$ lower during the remaining 6 hours, hence values of metabolic rate measurements made at temperatures of $35^{\circ}$ and $30^{\circ} \mathrm{C}$ respectively were used for the calculations.

A litter consisting of 4 young voles uses only 3.61 of oxygen during the first 9 days of life, whereas $R$ is distinctly higher in older individuals (Table 13). In individuals growing slowly the coefficient of productivity at the age of $1-9$ days (cf. Table 12) is $46.5 \%$, and $59.5^{\circ} \%$ in those growing quickly. However, in individuals from $10-18$ day old it

Table 13

Energy requirements and growth efficiency of a litter of 4 bank voles for successive $K=(P / A) \times 100 ; \quad A=P+R$ periods of the first month of life.

$K$ indicates coefficient of production efficiency; $P-$ tissue production (body gain); $R$ - respiration (cost of maintenance); $A$ - assimilation (sum total of production and respiration).

\begin{tabular}{|c|c|c|c|c|c|c|}
\hline \multirow{2}{*}{$\begin{array}{l}\text { Age } \\
\text { days }\end{array}$} & \multirow{2}{*}{$\begin{array}{l}\text { Mean } \\
\text { body } \\
\text { wt. } \mathrm{g}\end{array}$} & \multicolumn{2}{|c|}{$\begin{array}{r}\text { Oxygen consumption, } \\
\mathrm{mlg} \mathrm{hr^{ \prime }} \\
\end{array}$} & \multirow[t]{2}{*}{$\begin{array}{l}\text { kpal litter } \\
\text { per day }\end{array}$} & \multicolumn{2}{|c|}{ Efficiency $\mathbf{K}}$, \\
\hline & & At $30^{\circ} \mathrm{C}$ & At $35^{\circ} \mathrm{C}$ & & $1^{3}$ & $2^{3}$ \\
\hline $1--9$ & 12.4 & 1.51 & 1.30 & 1.93 & 59.5 & 46.5 \\
\hline $10-18$ & 25.2 & 2.27 & 3.02 & 8.22 & 19.3 & 9.4 \\
\hline $19-33$ & 44.0 & 2.90 & 3.31 & 33.87 & - & 4.5 \\
\hline
\end{tabular}

1 It was assumed that the female spends about 6 hours outside the nest during 24 -hour period, and during this period nest temperature was $30^{\circ} \mathrm{C}$. When the female was in the nest it was assumed that the young were in a temperature of approximately $35^{\circ} \mathrm{C}$. In order to simplify calculations it was also assumed that the group of oldest voles also live in the same ambient temperature as the younger individuals, which stay continually in the nest. 2 Variation in gross body composition were accepted after data given by Sawicka-Kapusta, 1974 (cf. Table 12). "Variations in gross body composition were accepted after data given by $F$ ed $\mathbf{y}$, 1974 b (cf. Table 12).

decreases considerably (Table 13). In the oldest of the litters examined it is only $4.5 \% / 4$, differing by more than ten times from that obtained for the youngest voles.

\subsection{Diseussion}

The indices calculated for production, although only approximate values, show clearly that growth efficiency in the bank vole changes radically during the animal's first month of life. On the first few days after birth, when the young do not leave the nest at all, their metabolic rate is relatively low, but the rate of increase in mass is no slower than that in older individuals, hence the ratio of energy deposited in the organism in the form of proteins and fats in relation to the amount of 
energy expended in maintenance is most favourable in the youngest individuals. At the age of $1-9$ days growth is as efficient in Clethriononiys glareolus as in certain birds (B rody, 1945). It must, however, be emphasised that this index is even more favourable in the rat (Widdowson, 1971), and several of the species of small birds examined (Dawson \& Evans, $1960 ;$ Myrcha, Pinowski \& Tomek, 1972; Diehl \& Myrcha, 1973).

In the bank vole at the age of $10-18$ days production efficiency is 3 - 5 times lower, despite the fact that it continues to remain relatively high and comparable with the efficiency measured in the laboratory mouse. In an experimental population of mice the value of the production coefficient for the first 26 days of life is $12.2 \%$ (M y r cha, 1975). Although significant changes in coefficient $K$ are observed in successive weeks of life, they are not correlated with age.

By the time bank vole reach the age of 18-33 days production efficiency is not high and is in fact the same as in another species of vole, e.g., Microtus arvalis, in which $K$ at the age of $20-30$ days equals $5.0^{4} /$ (D r ożdz, Górecki \& Sawicka-Kapusta, 1972). A decrease in the index of production efficiency in successive weeks of life was also found in the rat ( $\mathrm{W}$ id dow son, 1971). There is no doubt that bioenergetic parameters in these two rodents are subject to fundamental changes within a short time after birth. Tissue production efficiency is very high during the period when neither the rat nor the bank vole have an efficient thermoregulatory mechanism. The cost of depositing tissue is markedly higher during the time in which this mechanism begins to act efficiently and is highest in individuals possessing a fully developed capacity for regulating body temperature. The heat from the mother's body, warming the young voles huddled in a well constructed nest, enables them to maintain a stable temperature ( $\mathrm{f}$. sectıon 2) with a simultaneous low metabolic rate (section 4). During the first nine days of life the bank vole uses only a small amount of energy for respiration. At the age of $10-18$ days, when voles become fully homeothermal, maintenance costs continute to increase, so that after homeothermy has been reached these costs are twenty times greater than the amount of energy deposited in tissues in these still growing animals.

\section{GENERAL DISCUSSION}

Small mammals, as a rule, are born blind and incapable of independent life, only a small number of species belonging to the Micromammalia are similar to the majority of large mammals in this respect. Many of the physiological mechanisms, including those which regulate body tempe- 
rature, are still undeveloped at birth in small species. For instance there is no neural thermoregulation control in rats (C a pek et al., 1956). It cannot, however, be said that all mammals not fully developed at birth are at a uniform stage of development. The degree of formation of the functions connected with homeothermy varies in different species (Ge lineo, 1959; Poczopko, 1973), but mammals fully developed at birth can be justifiably considered as the opposite of all those species which acquire the capacity for independent life within a shorter or longer period after birth. Similarly, in another group of homeothermic animals - birds, there are many species possessing intermediate characteristics between typical nesting and non-nesting types. Leaving the question of the significance of such differentiation in degree of development aside, an attempt may be made at answering the question as to why small species of mammals are not fully developed at birth.

Reduction in body size involves a deterioration in the relation between body mass and its surface. This has in fact led P e a r s on (1948) to put forward the hypothesis that mammals weighing less than $2.5 \mathrm{~g}$ are incapable of maintaining a constant body temperature. This also applies to the period of postnatal development, in which many species of small mammals attain a state of homeothermy only after reaching a certain body size ( $\mathrm{Chew} \& \mathrm{Spencer}$, 1967). The smallest shrews of the genus Sorex so far examined are in fact homeothermic (Gębczy n$\mathrm{sk}$ i, 1971), although the body weight of some individuals of $S$. minutus is about $2 \mathrm{~g}$. It is only by maintaining a very high metabolic rate that Micromammalia keep their heat balance (see review by $\mathrm{Hart}$, 1971).

What then are the advantages of small body measurements? Reduction in body size allowed the occupation of new ecological niches which would otherwise have been impossible. Small species with lesser space and food requirements were able to adapt themselves to many habitats. The variety of such habitats is in fact immeasurably greater, and niches more varied, for small animals than for large ones. Although small body dimensions, and consequently the size of the brain cause reduction in wmental efficiency (S za r ski, 1967) the possibility of the creation of small species has become the basis of their evolutionary efficiency. Among mammals a group of this kind is formed by the rodents ( $\mathrm{R}$ ome r, 1959), which have reached peak development at the present time (S z a rski, 1967).

The advantages of small body dimensions are attained at the expense of the young animals being born not fully developed, as in the case of the vole. A large litter (on an average 4-6 young; $\mathrm{Z} \mathrm{e} \mathrm{j} \mathrm{d} \mathrm{a,} \mathrm{1966)} \mathrm{at}$ birth weighs nearly as much as the mother animal. It is impossible to 
imagine that gestation could last long enough for all the embryos to pass through all stages of development in utero. A different solution would be for only one individual to be born at a time, but the possession of numerous offspring is one of the important features of the dynamic character of these species and allows the rapid invasion of unoccupied habitat. Even the mortality during the first three weeks of life, affecting half the total number born (Ryszkowski \& Truszkowski, 1970), does not deprive the bank vole of this advantage. Offspring are thus born incompletely developed, but on the other hand the energy requirements of the pregnant female increase by only $24^{\prime \prime} / 4$ (K a c zmarski, 1966). The female, hampered in her movements by pregnancy when searching for food, is exposed to the notice of predators for a relatively short time. The virtual doubling of food requirements, shifted to the lactation period ( $\mathrm{Kacz}$ a $r \mathrm{ski}$, 1966), undoubtedly obliges the female to move about the area more frequently but by that time its agility is in no way diminished.

After birth bank voles are entirely dependent on maternal care. Therefore in order that the offspring may grow quickly and rapidly become independent they must be sure of suitable conditions for their development. Care of the young is manifested in complicated forms of behaviour. Many mammals display what Darwin called the warchitectural instincta (Barnett \& Mount, 1967). The female bank vole searches for a suitable place to build a nest, depending on local conditions ( $\mathrm{S} \mathrm{m}$ i r nov, 1968), and then builds a nest which effectively protects the litter from the efect of low temperatures. There can be no doubt that nest making is especially important to small mammals.

The female spends the greater part of the 24 hours with its offspring. warming them with the heat of her body. This is of particular importance during the first few days of life, as has been shown by experiments on the rat (Gel in e o, 1959), although probably all small mammals, and many large ones, sleep and rest in contact with others when they can. This is shown by the data given by specialists on behaviour ( $R$ h e i ngold, 1963), experiments made by physiologists (Mount, 1968), but also by ecologists' observations.

It has been shown that in several species of small rodents, including the bank vole, infants possess a way of calling for help by the emission of ultrasonic signals (Ok on, 1971; 1972). The temperature stimulus evokes emission of such signals and it may therefore be assumed that emission of ultrasonic signals enables the offspring to call the mother when temperature drops beyond a certain point.

Infant rodents can withstand a reduction in body temperature even down to $0^{\circ} \mathrm{C}$, but this property gradually disappears as they grow and 
their thermoregulatory capacity simultaneously develops (A dolph, 1957 ; L a gerspet $z$, 1962). It would. however, appear somewhat improbable that under natural conditions fluctuations in the body temperature of very young animals would exceed more than a few degrees C, since the nest hidden under the soil is exposed to relatively small variations in ambient temperature and its insulating properties can be very accurately suited to actual conditions of heat loss. In addition the offspring are able to warn the mother of a drop in temperature. Direct measurements of the body temperature of infant Glis glis (G ębc zy n ski, 1970), the rat (Poczopko, 1961), laboratory mice (Pichotk a, 1971), Meriones unguiculatus ( $\mathrm{M} \mathrm{cM}$ a n s, 1971) and Clethrionomys glareolus show that although it is lower than in adults, it does not fall below $30^{\circ} \mathrm{C}$. In all the above species the value of body temperature is on an average higher, and comes within limits of $32-36^{\circ} \mathrm{C}$. Measurements made on bank voles at different ambient temperatures, both in the laboratory and the enclosure, showed that the litters of this species have a stable body temperature ensured during the whole period of nest life. This is undoubtedly an important condition of their development, owing to which the intensive changes in the growing organism can take place quickly and without disturbance.

It is thus impossible to agree with the opinion that instability of body temperature is the main defence of the infants against detrimental environmental effects (Hahn \& Koldovek y, 1966; Okon, 1972). The capacity for surviving a very great drop in body temperature does not mean that young rodents ensure their existence in this way. This is refuted by the stability of body temperature found in infants in the nest. The fact that considerable cooling of young individuals leads to disturbances in their development rate may be even more convincing ( $\mathrm{H} \mathrm{a} \mathrm{r}$ $\mathrm{r}$ is on, 1963; Barnett \& Mount, 1967). All these considerations indicate that stability of body temperature is an essential condition of normal development in rodents.

It may be added in passing, in connection with the above discussion, that a rise in body temperature from $34^{\circ}$ to approx. $38^{\circ} \mathrm{C}$ during the postnatal development of the bank vole recalls the evolution of this character in mammals. The phylogenetic development of mammals is accompanied by an increase in thermoregulatory efficiency and a rise in the level of body temperature ( $\mathrm{Kuznicki} \& \mathrm{Urbanek}, 1967$ ).

The high and stable level of body temperature in newborn bank voles does not involve high energy expenditure. The total metabolic rate in the bank vole, as in many other species of small mammals (M o t $t, 1963$; Hill, 19̋61; His s a, 1968) is lowest during the first period of the animal's life and it is for this reason that tissue production efficiency 
can be so high. Although maintenance cost in comparison with weight gain increases as the animal grows larger ( $\mathrm{Brody}, 1945)$, the energetic efficiency of growth in nestling birds and small mammals is the highest in comparison with all other animals.

The physiological immaturity of newborn bank voles is also evident

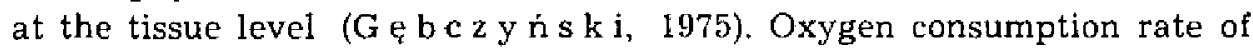
tissue homogenates changes with age. It also depends on the degree of physiological maturity of the animal, varying even with the time of its birth. In bank voles of the autumn generation, the body composition on the first day of life indicates that they are less mature chemically than individuals of the spring generation ( $\mathrm{F}$ e d y k, 1974b); they have also a different rate of tissue respiration. The energy metabolism of litters of both generations, on the other hand, does not differ in essentials (see section 5), and the energy costs of growth (section 6) are also uniform and independent of seasonal differences or differences caused by a change in ambient temperature.

The degree of development at birth may impose differences in growth rate and attainment of physiological maturity in ontogenesis, and therefore the period of growth in utero and postembryonic development supplement each other. This plasticity of reproduction in mammals, allowing the shifting of maternal care to either the prenatal or postnatal period, is outstanding indication of its progressiveness. The transfer of the costs connected with the rearing of offspring from the gestation period to the period of postnatal life in the nest was undoubtedly one of the causes which enabled the bank vole to occupy a wide variety of habitats over the whole of Euroasia. Development of this kind make it far easier for the bank vole, like other small mammals, to cope, at the expense of transitory helplessness, with the energetic problems of small size.

Acknowledgements: I wish to thank Professor Z. Pucek and Professor P. Poc zopko for constructive criticism of this paper. I further profited from discussion with A. Fedyk, S. Fedyk, A. Gorecki, M. Krasinska, E. Malzahn, J. Raczynski, E. Wolk. Thanks are due to J. Lipinska for her skillful technical assistance. I am especially grateful to my wife, Zofia, who assisted with some measurements and in the preparation of the manuscript. J. R. Flowerdew and G. L. Dry den kindly reviewed the English text.

\section{REFERENCES}

1. Ader R.\& Grota L. J., 1970: Rhythmicity in the maternal behaviour of Rattus norvegicus. Anim. Behav, 18: 144-150.

2. Adolph E. F., 1957: Ontogeny of physiological regulation in the rat. Quart. Rev. Biol., 32, 2: 89-137.

3. Antoschkina E. D., 1939: Razvitije termoregulacji: I. Razvitie termoregulacii u krys vozrašcaemyh v normalnyh uslovijah. Fizjol. Ż. SSSR, 26: 3-15.

4. Barić J., 1953: Contribution a la conaissance de l'ontogénèse du metabolisme de base. II. Le neutralité thermique et le métabolisme de base du cobaye nouveau-né. Bull. Acad. serbe Sci., Cl. Sci. mathem., 3: 77--83. 
5. Barnett S. A., 1956: Endothermy and ectothermy in mice at $-3^{\circ} \mathrm{C}$. J. exp. Biol., 33: 124-133.

6. Barnett S. A., 1973: Maternal processes in the cold-adaptation of mice. Biol. Rev. 48, 4: 477-508.

7. Barnett S. A. \& Little M. J., 1965: Maternal performance in mice at $-3^{i} \mathrm{C}$ : food consumption and fertility. Proc. Royal Soc., B, 162: 492-501.

6. Barnett S. A. \& Mount L. E., 1967: Resistance to cold in mammals. [In: "Thermobiology $\alpha$, ed. A. H. Rose]. Academic Press: 411-478. London, New York.

9. Bashenina N. W. \& Borovskaja E. M., 1963: Osobennosti razvitija termoregulacił polevok do mesjačnogo vozrasta. Bjul. Mosk. Obšč. Isp. Prir., $68,3: 34-45$.

10. Bergstedt B., 1965: Distribution, reproduction, growth and dynamics of the rodent species Clethrionomys glareolus (Schreber), Apodemus flavicollis (M lehior) and Apodemus sylvaticus ( $\mathrm{Linnej)} \mathrm{in} \mathrm{southern} \mathrm{Sweden.}$ Oikos, 16: 132-160.

11. Brody S., 1945: Bioenergetics and growth. Reinhold: XII + 1-1023. New York.

12. Buchalczyk A., 1970: Reproduction, mortality and longevity of the bank vole under laboratory conditions. Acta theriol., 15, 10: 153-176.

13. Bujalska G., Andrzejewski R. \& Petrusewicz K., 1968: Productivity investigation of an island population of Clethrionomys glareolus (S c h r e ber, 1780). II. Natality. Acta theriol., 13, 24: 415-425.

14. Bujalska G. \& Gliwicz J., 1968: Productivity investigation of an island population of Clethrionomys glareolus (Schreber, 1780). III. Individual growth curve. Acta theriol., 13, 25: 427-433.

15. Bujalska G. \& Rajska E., 1972: Obserwacje gniazd nornicy rudej i myszy wielkookiej leśnej $\mathrm{w}$ warunkach naturalnych. Przegl. zool., 16, 2: 227-230.

16. Cameron G. N., 1973: Effect of litter size on postnatal growth and survival in the desert woodrat. J. Mammal., 54, 2: 489-493.

17. Cassin S., 1963: Critical oxygen tensions in newborn, young and adult mice. Am. J. Physiol., 205: 325-330.

18. Chevillard L. R., Portet R. \& Cadot M., 1963: Growth rate of rats born at $5^{\circ} \mathrm{C}$ and $30^{\circ} \mathrm{C}$. Fed. Proc., 22: 699-703.

19. Chew R. M. \& Spencer E., 1967: Development of metabolic response to cold in young mice of four species. Comp. Biochem. Physiol., 22: 873-888.

20. Cosnier J,, Duveau A. \& Chanel J., 1965: Consommation d'oxygène et grégarisme du rat nouveau-né. C.r. Soc. Biol., 159, 7: 1579-1581.

21. Cotton M. J. \& Griffiths D. A., 1967: Observations on temperature conditions in vole nests. J. Zool, Lond., 153: 541-544.

22. Capek K, Hahn P., Kr̈ečk J. \& Martìnek J., 1956: Studie - fysiologii novoroženych mládát. Rozpr. Ceské Akad., 66: XII + 1--97.

23. Daws on W. R. \& Evans F. C., 1960: Relation of growth and dexelopment to temperature regulation in nestling vesper sparrows. Condor, 62, 5: 329-340.

24. Dawson W. R. \& Hudson J. W., 1970: Birds. [In: "Comparative physiology of thermoregulation $\alpha$, ed. G. Causey Whittow]. Academic Press: 223-310. New York, London.

25. DiehI D. \& Myrcha A, 1973: Bioenergetics of nestling red-backed shrices (Lanius collurio). Condor, 75: 259-264. 
26. Drożdì A., 1965: Wplyw myszy na dojrzewanie plciowe samców nornicy rudej (Clethrionomys glareolus Schr.). Zwierz. lab., 3, 1: 34-45.

27. Drożd $\dot{z}$ A., 1968: Digestibility and assimilation of natural foods in small rodents. Acta theriol., 13, 21: 367-389.

28. Drożdi A., Górecki A. \& Sawicka-Kapusta K., 1972: Bioenergetics of growth in common voles. Acta theriol., 17, 18: 245-256.

29. F a irfield J., 1948: Effects of cold on infant rats: body temperatures, oxygen consumption, electrocardiograms. Am. J. Physiol., 155: 355-365.

30. F e d y k A., 1974a: Gross body composition in postnatal development of the bank vole. I. Growth in captivity. Acta theriol. 19, 26: 381-401.

31. Fedyk A., 1974b: Gross body composition in postnatal development of the bank vole. II. Differentiation of seasonal generations. Acta theriol., 19, 27: 403-427.

32. Fitzgerald L. R., 1953: The oxygen consumption of neonatal mice. J. exp. Zool., 124: $415-425$.

33. Gelineo S., 1959: Razvitie gomotermii u mlekopitajuščih. Usp. sovrem. Biol., 47, 1: $108-120$.

34. Gelineo S. \& Gelineo A., 1950: Temperature gnezda pacova (Mus decumanus) i njen biološki znaćaj. Glas srp. Acad. Nauka, 196: 131-149.

35. Gelineo S. \& Gelineo A., 1951: Environmental temperature of the nest and the appearance of chemical thermoregulation in rats at the temp. of $21^{\circ} \mathrm{C}$. Bull. Acad. serbe Sci., Cl. Sci. math. nat., 3: 149-153.

36. Gelineo $S$. \& Gelineo A., 1952: La temperature du nid et sa signification biologique. Bull. Acad. serbe Sci., Cl. Sci. math. nat., 4: 197-210.

37. Gelineo S. \& Sokíc P., 1953: La naissance et ia dévelopmént de la thermorégulation chimique chez le spermophile (Citellus citellus). Bull. Acad. serbe Sci., Cl. Sci. math. nat., 3: $58-68$.

38. Gębczynska Z. \& Gębczynski M., 1971: Insulating properties of the nest and social temperature regulation in Clethrionomys glareolus ( $\mathrm{S} \mathrm{ch}$ rebe r). Ann, zool. Fennici, 8: 104-108.

39. Gebczynski M, 1969: Social regulation of body temperature in the bank vole. Acta theriol., 14, 29: $427-440$.

40. Gebczynski M., 1970: Development of temperature regulation in the fat dormouse. Acta theriol., 15, 23: 357-360.

41. Gebczynski M., 1971: The rate of metabolism of the lesser shrew. Acta theriol., 16, 20: 329-339.

42. Gębczyns i M., 1975: Tissue homogenates respiration in four species of growing voles. (in preparation).

43. Gorecki A., 1968: Metabolic rate and energy budget in the bank vole. Acta theriol., 13, 20: 341-365.

44. Hahn P., 1965: Effect of environmental temperatures on the development of thermoregulatory mechanisms in infant rats. Nature (Lond.), 178: 96-97.

45. Hahn P. \& Koldovsky O., 1966: Utilization of nutrients during postnatal development. Pergamon Press: XI + 1-177. Oxford.

46. Hahn P., Koldovsky O. Kr̆eček J., Martinek J. \& Vacek Z., 1961: Endocrine and metabolic aspects of the development of homeothermy in the rat. [In: "Somatic stability in the newly born", eds. G. E. W. Wolstenholme \& M. O'Connor]. Churchill: 131-148, London.

47. Harrison G. A., 1963: Temperature adaptation as evidenced by growth if mice. Fed. Proc., 22: 691-698. 
48. H a r t J. S., 1971: Rodents. [In: "Comparative physiology of thermoregulation. II. Mammalsa, ed, G. Causey Whittow]. Academic Press. 1-149. New York, London.

49. Hill J. R, 1961: The physic and physiology of the developmant of homeothermy. [In: wSomatic stability in the newly born*, eds. G. E. W. Wolstenholme \& M. O'Connor]. Churchill: 156-169. London.

50. Hill R. M., 1947: The control of body-temperature in white rats. Am. J. Physiol., 149: 650-656.

51. Hill R. W., 1972: The amount of maternal care in Peromyscus leucopus and its thermal significance for the young. J. Mammal., 53, 4: 774-790.

52. H is s a R., 1968: Postnatal development of thermoregulation in the Norwegia: lemming and the golden hamster. Ann. zool. fenn., $5: 345-383$.

53. How a d W. E., 1949: Dispersal, amount of inbreeding, and longevity in a local population of prairie deermice on the George Reserve, Southern Michigan. Contr. Lab. Vertebrate Biol., 43: 1-50. Ann Arbor.

54. Ilyenko A. J. \& $\mathrm{Zubchaninova} \mathrm{E.} \mathrm{V.,} \mathrm{1963:} \mathrm{Kruglogodienye} \mathrm{nablu-}$ denija za mečnymi ryżimi polevkami i lesnymi myšami v Podmoskove. Zooi. Z., 42, 2: 609-617.

55. Irring L, \& $\mathrm{Krog} \mathrm{J}$, 1956: Temperature during the development of birds in arctic nests. Physiol. Zöol., 29, 3: 195--205.

56. Kaczmarski F., 1966: Bioenergetics of pregnancy and lactation in the bank vole. Acta theriol., 11, 19: 409-417.

57. Kalabukhov N. J., 1951: Metodika eksperymentalnych issledovanii po ekonogii nazemnyh pozwonolnyh. Gos. Izd. Sov. Nauka: 1-177. Moskva.

58. Karulin B. E., Shilov I. A., Nikitina N. A., Soldatova A. N., Kovalevsky Yu. V., Khlyap L. A., Ivashkina I. N. \& Dubrovsky Yu. A., 1973: Sutožnaja aktirnost' i ispolzovanie territorii ryžej polevkoj (Clethrionomys glareolus) zimoj po nabludenijam za zverkami, mečenymi radioaktivnym kobaltom. Zool, Z, 52, 5: 743-750.

59. Kayser C. \& Heusner A., 1967: Le rytme nycthéméral de la dépense d'énergie. Etude de physiologie comparée. J. Physiol., Paris, 59, 1: 3--116.

60. Kendeigh $\mathrm{S}$. C., 1952: Parental care and its evolution in birds. 11l. Biol. Monographs, 22, 1-3: X $+1-356$. Urbane.

61. K inder E. F., 1927: A study of the nest building activity of the albino rat. J. exp. Zool., 47: 117-161.

62. $\mathrm{K}$ ing J. A., 1963: Maternal behavior in Peromyscus. [In: Maternal behavior in mammals, ed. H. L. Rheingold]. John Wiley \& Sons: 58-93. New York, London.

63. Kleiber M., 1961: The fire of life - and introduction to animal bioenergetics. John Wiley \& Sons: 1-454. New York, London.

64. Korabelnikov V. M., 1972: Zavisimost' rosta i postémbrionalnogo razvitija ryżej polevki (Clethrionomys glareolus Schreb.) ot veličny vyvodka. Zool. Zे, 51, 3: 464-466.

65. Kostelecka-M y cha A., 1973: Regularities of variations of the haematological values characterizing the respiratory function of blood in mammals. Acta theriol., 18, 1: $1-53$.

66. Kubik J., 1965: Biomorphological variability of the population of Clethrionomys glareolus (S chreber, 1780). Acta theriol., 10, 10: 117-179.

67. Kúfickj L. \& Urbanek A., 1967: Zasady nauki o ewolucji. Państw. Wyd. Nauk., 1: 1-617. Warszawa. 
68. L a gerspet $z \quad K$., 1962: The postnatal development of homoiothermy and cold resistance in mice. Experientia, 18: 1-.5.

69. Lagerspetz K. Y. H., 1966: Temperature relation of oxygen consumption and motor activity in newbern mice. Ann. Med. exp. Fenn., $44: 71-73$.

70. Layne J. N., 1969: Nest-building behavior in three species of deer mice, Peromyscus. Behaviour, 35, 3-4: 288-303.

71. Leichtentritt B., 1919: Die Wärmeregulation neugeborener Säugetiere und vögel, Zeitschr. 1. Biol., 69: 545-563.

72. M a zák V., 1962: Zur Kenntnis der postnatalen Entwicklung der Rötelmaus, Clethrionomys glareolus Schreber, 1780 (Mammalia, Microtidae). Věst. ceskosl. společn. zool., 26, 1: 77-104.

73. M c M a n us J. J., 1971: Early postnatal growth and the development of temperature regulation in the Mongolian gerbil, Meriones unguiculatus. if. Mammal., 52, 4: 782-792.

74. Morrison P. R., Ryser F. A. \& Strecker R. L., 1954: Growth and the devclopment of temperature regulation in the tundra redback vole. J. Mammal., 35, 3: 376-386.

75. Mott J. C., 1963: Oxygen consumption of the newborn. Fed. Proc., 22: 814 -817 .

75. Mount L. E., 1960: The influence of huddling and body size on the metabolic rate of the young pig. J. agric. Sci., 55, 1: 101-105.

77. M o u $\mathrm{t}$ L. E., 1968: The climatic physiology of the pig. Arnold: IX $+1-271$. London.

78. Mourek J., 1958: The effect of hypoxia on oxygen consumption and body temperature during ontogenesis in normal and decorticated rats. Physiol. Bohemuslov., $7: 399-408$.

79. Myrcha A., 1975: Bioenergetics of an experimental population and individual laboratory mice. Acta theriol., 20, 16: 175-226.

80. Myrcha A., Pinowski J. \& Tomek A., 1972: Energy balance of nestling of tree sparrows, Passet $m$, montanus (L.). [In: "Productivity, population dynamics and systematics of granivorous bird", ed.: S. S. Kendeigh \& J. Pinowski]. Panstw. Wyd. Nauk.: :59-83. Warszawa.

81. Myrcha A. \& Szwykowska M. M, 1969: Interrelation between duminance in the population and the level of metabolism in white mice males. Bull. Acad. Pol. Sci., Cl. II, 17; 599-601.

82. Okon E. F., 1971: Temperature relations of vocalization in infant golden hamster and Wistar rats. J. Zool, Lond., 165: 227-237.

83. Ok on E. E., 1972: Factors affecting ultrasound production in infant rodents. J. Zool., Lond., 168: 139-148.

84. Ostby e E., 1965: Development of thermoregulation in relation to age growth in Norwegian lemming (Lemmus lemmus L.). Nytt Mag. Zool., 12: 65-75.

85. Pearson A. M., 1962: Activity patterns, energy metabolism, and growth rate of the voles Clethrionomys rufocanus and $C$. glareolus in Finland. Ann. Soc. zool.-bot. fenn, wVanamo*, 24: 1- 58.

86. Pearson O. P., 1948: Metabolism of small mammals, with remarks on the lower limit of mammalian size. Science, $108: 44$.

87. Pegelman S. G., 1966: Adaptivnoe gnezdovoe povedenie nekotoryh vidov dikih i laboratornyh životnyh. Zurn. obšč. Biol., 27, 3: 331-335.

88. Pegelman S. G. \& Korabelnik ov V. M., 1972: velicina vyrodkov i temp rozvitija potomstwa u gryzunov. Ekologija, 2; 36-43. 
89. Pembrey M. S., 1895: The effect of variation in external temperature upon the output of carbonic acid and the temperature of young animals. J. Physiol., Lond., 18: 363-379.

90. Petrov O. V. \& Ajrapetjanc A. E., 1961: O rozmnożenii i pervyh stadiah postembrionalnogo razvitia ryżej polevki $v$ laboratornyh uslovijalı. Vestn. Leningr. Univ, 21, 4: 51-61.

91. Pichotka J. P., 1971: Chemical thermoregulation in poikilothermic new-born mice. J. Physiol., Paris, 63, 3: 376-379.

92. Pincus G., Sterne G. D. \& Enzmann E., 1933: The development of temperature regulation in the mouse. Proc. Nat. Acad. Sci., 19: 729-733.

93. Poczopko P., 1961: A contribution to the studies on changes of energy metabolism during postnatal development. I. Development of mechanisms of body temperature regulation in rats. J. cell. comp. Physiol., 57: 175-184.

94. Poczopko P., 1969: The development of resistance to cooling in baby rabbits. Acta theriol., 14, 31: 449-462.

95. Poczopko P., 1973: Niektóre aspekty termoregulacji we wczesnych okresach życia postembrionalnego ptaków i ssaków. Acta physiol. pol., 24, 3: supl., 6: $101-115$.

96. Ponugaeva A. G., 1960: Fizjologičeskie issledoranija instinktov u mlekr:pitajuščih. Izd. AN SSSR: 1-180. Moskva-Leningrad.

97. Precht H., Christopherson J. \& Hensel H., 1955: Temperatur und Leben. Springer-Verlag: VII+1-514. Berlin-Göttingen-Heidelberg.

98. Pr y c hodk o W, 1958: Effect of aggregation of laboratory mice (Mus musculus) on food intake at different temperatures. Ecology, 39, 3: 499-503.

99. Pucek Z., 1958: Untersuchungen über Nestentwicklung und Thermoregulation bei einem Wurf von Sicista betulina pallas. Acta theriol, 2, 2: 11-54.

100. Rheingold H. L., 1963: Maternal behavior in mammals. John Wiley \& Sons: I-349. New York, London.

101. Röđl P., 1973: Vliv pozmienaneho počtu mladát ve vrhu na rủst váhy a ostatnich tẻlesných znakù u nornika rudého, Clethrionomys glareolus $\mathrm{S}$ ch $\mathrm{r}$ eber, 1780. Lynx, 14: 29-37.

102. Romer A. S., 1959: The vertebrate story. Univ. of Chicago Press: VII+1-437. Chicago.

103. Rosenblatt J. S. \& Lehrman D. S., 1963: Maternal behavior of the laboratory rat. [In: "Maternal behavior in mammals $\alpha$, ed: H. L. Rheingoldi, John Wiley \& Sons: 8-57. New York, London.

104. Ryszkowski L. \& Truszkowski J., 1970: Survival of unweaned and juvenile bank voles under field conditions. Acta theriol., 15, 15: 223-232.

105. Sawicka-Kapusta K., 1974: Changes in the gross body composition and energy value of the bank vole during their postnatal detrelopment. Acta theriol., 19, 3: 27-54.

106. Shilov I. A., 1968: Regulacija teploobmena u ptic. Izd. Moskcv. Univ,: 1-125. Moskva.

107. Smirnov P. K., 1968: Ekologo-fizjologiceskoe issledovanie nekotoryh ridov gryzunov. Izd. Nauka: 1-133. Leningrad.

108. Sviridenko P. A., 1959: Rost i razvitie evropejskoj ryžej polevki (Clethrio. nomys glareolus Schreb.). Zool. Ż, 38, 5: 756-766.

109. Szarski H., 1967: Historia zwierząt kregowych. Panistw. Wyd. Nauk,: 7-467. Warszawa. 
110. Tay lor P., 1960a: Oxygen consumption in new-born rats. J. Physiol, Lond., 154: $153-168$.

111. Taylor P., $1960 \mathrm{~b}$ : The influence of environmental temperature on the $\mathrm{O}_{2}$ consumption of new-born rats. J. Physiol., Lond., 151 P: 22-23.

112. Truszkowski J., 1974: Utilization of nest boxes by rodents. Acta theriol., 19, 29: 441-452.

113. Várnai I. \& Donhoffer S., 1970: Thermoregulatory heat production and regulation of body temperature in the new-born rat. Acta physiol. Acad. Sei. hung., $37,1 / 2: 35-49$.

114. Vetulani T., 1931: Untersuchungen über das Wachstum der Säugetiere in Abhängigkeit von der Anzahl zusammengehaltener Tiere. I Teil. Beobachtungen an Mäusen. Biologia generalis, $7: 71-98$.

115. Wasilewskj W., 1952: Badanja nad morfologia Clethrionomys glareolus glareolus Schreb. Annls Univ. M. Curie-Sklodowska, C, 7, 3: 119-211.

116. Widdows on E. M., 1971: Food intake and growth in the newly-born. Proc. Nutr. Soc., 30, 2: 127-135.

117. Zejda J., 1966: Litter size in Clethrionomys glareolus Schreber 1780. Zool. listy, 15, 3: 193-208.

118. $\mathrm{Z}$ e j d a J., 1968: A study on embrione and newborn of Clethrionomys glareolus Schreb. Zool. listy, 17, 2: 115-126.

119. Zejda J., 1971: Differential growth of three cohorts of the bank vole, Clethrionomys glareolus Schreb. 1780. Zool. listy, 20, 3: 229-245.

Accepted, February 11, 1975.

Mammals Research Institute,

Polish Academy of Sciences,

17-230 Bialowieża, Poland.

Marek GF̨BCZYNSKI

ROZWOJ STAEOCIEPLNOSCI I ENERGETYCZNE KOSZTY WZROSTU

U NORNICY RUDEJ W PIERWSZYM MIESIACU ZYYIA

\section{Streszczenie}

Badania przeprowadzone na nornicy rudej, Clethrionomys glareolus (S ch r e ber, 1780) miały za cel poznanie nie tylko fizjologicznych reakcji nornic $w$ okresie ich pierwszego miesiąca życia, ale także ocenę rzeczywistych warunków bytowania młodych. Dokonano też próby ustalenia, czy sezon urodzenia modyfikuje tempo rozwoju w początkowych tygodniach życia.

Stwierdzono, że temperatura ciala nornicy rudej wynosi $w$ wieku od 1 do 9 dnia życia, okolo $33-34^{\circ} \mathrm{C}$, w wieku $10-18$ dni cechuje się równomiernym wzrostem, by okolo dziewiętnastego dnia po urodzeniu osiagnace $37-39^{\circ} \mathrm{C}$, poziom wlaściwy osobnikom doroslym (Ryc. 1). Pomiary w laboratorium, przy temperaturze środowiska $18--21^{\circ}$ i $4-7^{\circ} \mathrm{C}$ (Tabela 2) a także w zagrodzie przy 2-12 ${ }^{\circ} \mathrm{C}$ (Tabela 3) wskazuja, że temperatura ciała gniazdujących nornic podlega tylko niewielkim wahaniom. Ponieważ pomiary cieploty ciala u nowourodzonych nornic nastręczaja kłopoty metodyczne, dlatego też wykonano dodatkowe doświadczenia, ktōre wska- 
zały, że temperatura $\mathrm{w}$ dole pachowym, regio axillaris, dobrze oddaje wartosei whaściwe wnętrzu ciala (Tabela 1).

W pierwszym tygodniu życia opornośc nornic na działanie chlodu jest mala i choć wzrasta ona stopniowo $z$ wiekiem, to dopiero $w$ końcu drugiego tygodnia życia staje się wyraźna (Tabela 4). Oporność na ochladzanie jest niero większa u nornic trzymanych razem $w$ miocie, $w$ porównaniu do osobników rozląezonych ná czas doświadczenia (Ryc. 2). Jeszcze większą ochronę stanowi gniazdo, które może aż pięciokrotnie zmniejszyć tempo zniżania się temperatury ciepla u przebywających w nim noworodków (Ryc. 3).

Bardzo ważnym czynnikiem pozwalającym na stworzenie termieznie stabilnych warunków rozwoju gniazdowego jest także behawior macierzyński. Przejawia się to $\mathrm{m}$. in. $\mathrm{w}$ ekstensywnym ogrzewaniu mlodych $\mathrm{w}$ ciagu wiekszości okresu doby (Ryc. 4, 5; Tabela 5). Tempo metabolizmu jest u noworodkow niskie i wzrasia dopiero pod koniec drugiego tygodnia życia (Ryc. 9). Działanie chłodu przez 15 minut powoduje jednak wyraźny wzrost zużycia tlenu, już w pierwszych dniach po urodzeniu (Ryc. 7, 8). U osobniksw w wieku 10-18 dni zużycie tlenu przy 15 i $20^{\circ} \mathrm{C}$ jest wyższe niż u starszych (Tabela 6), co swiadczy o rozwoju mechanizmów produkcji ciepla a braku pelnej zdolności do kontroli nad jego utrata Reaiscja metaboliczna na chlód u osobników pochodzących z miotów pojedynczych może być dwukrotnie wyższa niż u miotów złożonych z 3 lub więcej młodych (Tabela 7; Ryc. 6). Tempo metabolizmu osobników branych z miotów na czas pomiaru nie charakteryzuja $w$ żadnym stopniu miotów, $z$ których one pochodza, gdyż jest inne i mniej zależne od wieku (Tabela 8 ).

Dane o zużyciu tlenu przez nornice urodzone $w$ generacji wiosennej i jesiennej wskazuja, że istnieje pewne zwolnienie tempa rozwoju u osobników urodzonych jesienia (Ryc. 10; Tabela 9). Różnice te jednak nie są na tyle duże by można powiedzieć, że wzorzec rozwoju obu generacji jest inny.

$Z$ większenie zapotrzebowania energetycznego potrzebnego do odchowania miodych, wynosi okolo $10 \mathrm{kcal}$ energii asymilowanej na $1 \mathrm{~g}$ przyrostu miotu na cieżarze. Zależy ono tylko od tempa przyrostu ciężaru ciała potomstwa, bowiem bylo podobne $w$ grupie zimowej, rosnącej wolno przy temperaturze otoczenia $20^{\circ} \mathrm{C}$ i w grupie wiosennej, rosnącej szybko przy 9 i $20^{\circ} \mathrm{C}$ (Tabela 10, 11). Ilosć energii deponowana przez mlode nornice $w$ początkowych dniach po urodzeniu może osiągac $60 \%$ energii asymilowanej, a $u$ osobników $w$ wieku $10-18$ dni waha sie między 10 a $20 \%$, podczas gdy u starszych nie przekracza $5 \%$ (Tabela 12, 13).

Zatem niskje tempo metabolizmu osobników gniazdujacych pozwala temu gatunkowi, dzięki opiece macierzyńskiej, na stworzenie warunków do rozwoju mlodych przy niskich nakładach energetycznych. 